\author{
Cristián Román Cordero ${ }^{1 *}$
}

\title{
El Debido Procedimiento Administrativo Sancionador
}

* Instructor

de Derecho Administrativo Universidad de Chile.
"Cada uno de ellos tiene sus leyes (un juego deportivo, v.gr., el fútbol y el proceso -nota nuestra-); y el público que asiste a la una o al otro, si no las conoce, no comprende nada; y si las reglas no son justas, también los resultados en la representación o el proceso corren riesgo de no ser justos, lo cual, cuando se trata de un partido de fútbol o boxeo, puede no ser una tragedia, pero cuando la apuesta es la propiedad o la libertad, amenaza precisamente al fin del fundo, que tiene necesidad de paz para hacer su recorrido, pero la paz tiene necesidad de justicia, como el hombre de oxígeno para respirar."

(Carnelutti,. Francesco, Cómo se hace un proceso, Editorial Temis, Bogotá, 1989, p. 5.)

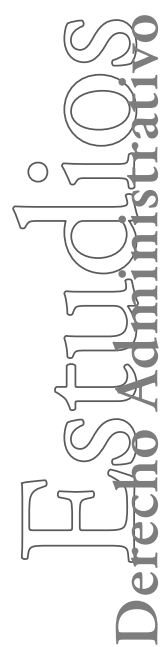

\section{Introducción}

El ejercicio por parte de la Administración del Estado de potestades sancionadoras es una realidad, hoy por hoy, innegable y que crece exponencialmente. Respecto de ellas la jurisprudencia constitucional ha señalado que si bien su ejercicio no importa jurisdicción, éste, igualmente, debe conformarse a ciertos principios garantistas de orden sustantivo como adjetivo -o procedimentales-. En este sentido, ha afirmado que al Derecho Administrativo Sancionador se aplican los derechos y garantías consultados en el artículo 19 No 3 "por regla general" o "con matices". En este contexto, la doctrina ha centrado el estudio de esta cuestión en el aspecto sustantivo, esto es, si son o no aplicables a aquella rama del Derecho los principios propios del Derecho Penal y en caso de serlo, en qué forma o intensidad, dejando un tanto olvidado el

\footnotetext{
El autor agradece desde ya cualquier comentario sobre el presente trabajo al e-mail: croman@derecho.uchile.cl
} 
aspecto procedimental, no obstante su trascendental importancia, la que con nitidez se aprecia si se observa que en el ejercicio de tales potestades se resuelven aspectos de singular relevancia, muchos de los cuales se hallan relacionados a derechos fundamentales, lo que por sí explica la importancia que en esta hipótesis adquieren las muchas veces despreciadas formas. Pues bien, en el presente trabajo abordaré precisamente los fundamentos y características del debido procedimiento administrativo sancionador.

Para este cometido, como marco general, trataré, en primer lugar, los fundamentos que justifican la atribución de tales potestades a la Administración y la necesidad de su limitación; luego, me referiré a la naturaleza jurídica de aquéllas, la autonomía del Derecho Administrativo Sancionador -rama que las estudia- y su frontera, que representa el concepto "sanción administrativa”, y finalmente abordaré los principios a los que debe conformar la Administración su ejercicio, sustantivos o adjetivos -procedimentales-, explayándome, especialmente, en estos últimos.

Al final de este trabajo, atendida su importancia, me permitiré transcribir íntegramente el proyecto de ley de bases de los procedimientos administrativos sancionatorios, del año 2004, que lamentablemente fuera retirado, por constituir, con todos sus virtudes y defectos, el único intento legislativo que en nuestro país ha existido en orden a establecer, en forma general, principios sustantivos y adjetivos del Derecho Administrativo Sancionador, y un procedimiento administrativo sancionador con carácter general y supletorio.

\section{Las potestades sancionadoras de la Administración del Estado}

\section{Estado de la cuestión}

Desde el momento mismo en el que es posible hablar de Administración en los términos que hoy la entendemos ${ }^{2}$, aquélla tiene atribuidas potestades sancionadoras. Así, por ejemplo, el libro Principios Elementales de Derecho Administrativo Chileno, primero en Chile y Latinoamérica sobre la especialidad ${ }^{3}$, de 1859 , atribuido a don Santiago Prado, ya se refería a ellas. Sobre el particular puntualiza que su atribución a la Administración debía ser, en primer lugar, excepcional, razón por la cual, entendió, aquello debía estar reservado a la ley, y en segundo lugar, limitada, esto es, las sanciones que la Administración podía, en su ejercicio, imponer en caso alguno debían exceder la "simple corrección o por vía de disciplina”. Criterios que siguieron, por una parte, el

Sobre el particular véase: GIANINNI, Massimo Severo. Premisas Sociológicas e Históricas del Derecho Administrativo. 1era edición, Madrid, Instituto Nacional de Administración Pública, 1980.

Cfr. VILLEGAS BASAVILBASO, Benjamín. Derecho Administrativo. 1era edición, Buenos Aires, Tipográfica Editora Argentina, 1949, Tomo I, p. 49. En el mismo sentido, recientemente: GUZMÁN BRITO, Alejandro. "El primer libro de Derecho Administrativo editado en Chile: "Los Principios Elementales de Derecho Administrativo Chileno”, de Santiago Prado”, en ARANCIBIA MATTAR, Jaime y MARTINEZ ESTAY, José Ignacio (coord.). La Primacía de la Persona. 1era edición, Santiago, Editorial Legal Publisching, 2009.

$4 \quad$ La posición del mencionado autor puede apreciarse en el siguiente párrafo extraído de su Principios Elementales de Derecho Administrativo: "La independencia de la administracion estaria comprometida sino tuviese ninguna 
Código Penal de 1875, al establecer que la Administración podía imponer sanciones, mas ellas no debían exceder las señaladas en su Libro III, salvo que una ley expresamente dispusiera lo contrario ${ }^{5}$, y por otra, la doctrina, de manera casi uniforme ${ }^{6}$, durante el siglo XIX y buena parte del siglo XX' .

Ahora bien, hace poco más de medio siglo, especialmente en las últimas décadas, se aprecia un crecimiento exponencial de la cantidad de órganos administrativos que han sido dotados con tales potestades por ley expresa ${ }^{8}$, así como de la lesividad de las sanciones que éstos pueden imponer en su ejercicio, fenómeno que por enorme e inorgánico he denominado elefantiasis de las potestades sancionadoras de la Administración?.

potestad coercitiva o careciese absolutamente de facultades para exijir la fiel observancia de sus actos, aplicando penas pecuniarias dentro de los límites de la simple corrección o por vía de disciplina. El poder legislativo delega en la administracion esta parte de funciones propias del órden judicial, a fin de robustecer su acción i completar su existencia, reservando el conocimiento de las causas graves i de los delitos contra la autoridad a los jueces competentes" (sic) PRADO, Santiago. Principios Elementales de Derecho Administrativo Chileno. 1era edición, Santiago, Imprenta Nacional, 1859 , p. 24.

5 En efecto, el artículo 501 del Código Penal dispuso: "En las ordenanzas municipales y en los reglamentos generales o particulares que dictare en lo sucesivo la autoridad administrativa no se establecerán mayores penas que las señaladas en este Libro, aun cuando hayan de imponerse en virtud de atribuciones gubernativas, a no ser que se determine otra cosa por leyes especiales".

6 El gran crítico a la atribución legal es estas potestades fue en el siglo XIX Jorge Huneeus, quien sobre el particular sostuvo: "Es algo que parece inesplicable, por ejemplo, cómo el artículo 106 de la lei del réjimen interior pudo conferir jurisdicción a los Gobernadores para imponer multas que no excedieran de veinticinco pesos, o, en su defecto, prisión que no excediera de cuarenta i ocho horas, a los individuos que les desobedecieran o faltaran al respecto, i a los que turbaran el órden o sosiego público; i como el artículo 120 de la misma lei pudo conferir facultad a aquellos funcionarios para imponer hasta un mes de prision o hasta veinticinco palos, a los soldaddos de policía i a otros ajentes de la misma clase, que incurrieran en faltas u omisiones que no tuvieran pena determinada en el Código criminal. (/) Hoi, por fortuna, nuestro Código Penal tiene previstos los casos a que esas dos disposiciones se refieren, i ha derogado, por consiguiente, o dejado sin efecto la anómala jurisdicción que ámbas atribuian a los Gobernadores departamentales, evitando así que éstos puedan ser jueces en causa propia i que puedan aplicar paternalmente la pena de palos a los infelices subalternos de la policía. !El rubor asoma a las mejillas cuando se piensa que semejante réjimen, abiertamente contrario a la Constitución i a los sanos principios, ha sido, sin embargo, el réjimen legal de nuestra República durante largos ańos!" HUNEEUS, Jorge. La Constitución ante el Congreso. 1era edición. Santiago, Imprenta de "Los Tiempos", 1880, tomo II, p. 244. Así, por ejemplo, un libro intitulado Derecho Administrativo, sin autor, de 1929, seńala en este sentido que: "La potestad correctiva, como se ha dicho, se aplica a los administrados cuando infringe alguna disposición administrativa. Esta potestad se contiene en la ley, pero más generalmente en los reglamentos orgánicos y se le da a la autoridad correspondiente y al jefe del servicio. Las correcciones no tienen el carácter de pena. En primer lugar por su naturaleza misma y en segundo, porque, como dijimos en otra ocasión, así lo establece el art. 20 del Código Penal. De eso se deduce que las correcciones no producen el efecto que llevan aparejadas las penas, como inhabilidad, etc. Las correcciones tiene un segundo carácter distintivo y es el no poder constituir un castigo mayor que el del Código citado impone a las faltas, salvo que la ley administrativa disponga otra cosa. Esto lo prescribe el art. 501 del Código Penal". Autor desconocido. Derecho Administrativo. Santiago, 1929, p. 48. En todo caso no es posible dejar de observar la lamentable omisión que sobre el tema se advierte en las obras holísticas de la especialidad en el periodo referido.

8 Cfr. FUENTES HURTADO, Martín. Derecho Administrativo Penal. 1era edición, Santiago, Editorial Universitaria, 1954. Por ello, Aróstica Maldonado sostiene que, "a poco andar el siglo XX, la referencia cuasi marginal que el artículo 501 hacía a las "leyes especiales" abre las puertas, de par en par, a los poderes sancionatorios administrativos, por medio de un cúmulo enorme e incoherente de preceptos legales en tal sentido" Aróstica Maldonado, Iván, "Un Lustro de Sanciones Administrativas (1988-1992)", en Revista de Derecho Público, Departamento de Derecho Público, Facultad de Derecho, Universidad de Chile, No 50, julio-diciembre 1991, p. 77.

9 ROMÁN CORDERO, Cristian. "Los principios de Derecho Administrativo Sancionador", en Revista de Derecho Público, Departamento de Derecho Público, Facultad de Derecho, Universidad de Chile, No 69/2, 2007, p. 24 y ss. 


\section{Criticas a la atribución legal de potestades sancionadoras a la} Administración del Estado

Este fenómeno ha sido cuestionado por un importante sector doctrinario. Para ello se ha afirmado que dicho fenómeno constituye una irrupción desmedida de la Administración en el libre juego de las leyes del mercado ${ }^{10} \mathrm{y}$, además, que la atribución de tales potestades a la Administración contravendría la Constitución, ya que, sostienen Aróstica Maldonado ${ }^{11}$ y Soto Kloss ${ }^{12}$, coincidiendo con lo señalado hace más de un siglo por don Jorge Huneeus ${ }^{13}$, sancionar es juzgar y quien puede juzgar, a la luz de la Carta Fundamental, sólo es el juez, mas no el administrador.

\section{Critica a las criticas a la atribución legal de potestades sancionadoras de la Administración del Estado.}

En primer lugar cabe observar que el ejercicio de las potestades sancionadoras por parte de la Administración no importa jurisdicción, como afirman los autores antes

10 Sostiene al respecto Aróstica: "Resulta verdaderamente paradojal comprobar que mientras se viene abogando por el "fin del estatismo", esto es, por el término o al menos la reducción de omnímodos poderes en manos de la Administración, en aras de concretar el justo equilibrio que entre éstos y los derechos de los ciudadanos requiere una sociedad verdaderamente libre, no se ha reparado mientes en la conservación e incluso aumento que han experimentado sus potestades sancionadoras con respecto a esos particulares" ARÓSTICA MALDONADO, Iván, Op. Cit., p. 71.

11 Aróstica Maldonado ha planteado: "De esta forma, perfectamente puede concluirse que la potestad sancionadora administrativa es totalmente inconstitucional, ya que la facultad de imponer penas y sanciones por contravenciones a la normativa vigente le corresponde exclusivamente a los únicos órganos jurisdiccionales: los Tribunales de Justicia, por expresa disposición del inciso cuarto del № 3 del artículo 19 y del artículo 73, ambos de la Constitución” ARÓSTICA MALDONADO, Iván. "Algunos problemas del Derecho Administrativo Penal”, en Revista de Derecho, Universidad de Concepción, No 182, 1987, p. 74.

12 Por su parte, Soto Kloss ha planteado que, "si sancionar es juzgar, y si para juzgar se requiere estar habilitado jurídicamente por la Constitución y el ordenamiento constitucional, y ello en Chile se ha entregado a los tribunales de justicia, y más encima ello debe hacerse a través del debido procedimiento (racional y justo), no parece sino elemental el preguntarse ¿̨cómo, entonces, el administrador -sea el Presidente de la República, un jefe de servicio, un intendente, etc.- puede imponer sanciones administrativas sean multas, sean comisos, sean clausuras de locales, sean retiros de actos autorizatorios, sean conductas determinadas, etc. si carece constitucionalmente de jurisdicción? Si el Presidente de la República carece de toda potestad jurisdiccional, y para ordenar detenciones la Constitución ha debido regular expresamente tal posibilidad, y para el caso del estado de sitio jcómo es que la Administración que le está subordinada puede imponer sanciones? Porque es una realidad que día a día la Administración impone castigos, no sólo a sus agentes (funcionarios), sino a los simples ciudadanos, a los usuarios de servicios públicos, a quienes contratan con ella, a quienes son beneficiarios de una autorización, de una subvención, de un acto de admisión, en fin de cualquier acto administrativo de beneficio" SOTO KLOSS, Eduardo. "Derecho Administrativo Penal. Notas para el estudio de la potestad sancionadora de la Administración”, en Boletín de Investigaciones, Facultad de Derecho, Pontificia Universidad Católica de Chile, № 44 /45, 1979/1980, pp. 95 y ss.

13 Este autor señaló sobre el particular lo que sigue: "No se concibe, en efecto, cómo un hecho al cual la lei no señala pena pudiera ser delito, i cómo es posible que, señalándosela una lei especial, sólo porque ésta no tiene el nombre o título de Código Penal, o sólo porque no forma parte de éste, ese hecho pueda ser castigado por otra autoridad que los Tribunales Ordinarios de Justicia. Según este curioso sistema, el hecho prohibido i castigado por la lei era o no era delito, tomando en cuenta solamente si esa ley formaba o no parte del Código Criminal, según las palabras de nuestra ley de réjimen interior. ¡Es concebible absurdo semejante?” HUNEEUS, Jorge. La Constitución ante el Congreso. 1era edición. Santiago, Imprenta de "Los Tiempos", 1880, tomo II, p. 244-245. 
citados, sino que constituye sólo una actuación de orden administrativo, planteamiento este último con el cual dicha crítica pierde todo sustento. En este sentido, preciso es señalar que recientemente el Tribunal Constitucional ha observado que "el procedimiento que regula el artículo 161 del Código Tributario y en virtud del cual se le otorga la facultad al Director Regional del Servicio de Impuestos Internos -o al funcionario que éste designe al efecto- para aplicar multas, importa en la especie el ejercicio de facultades sancionatorias administrativas y no jurisdiccionales, razón por la cual no puede estimarse que exista una contravención al artículo 76 de la Carta Fundamental;" ${ }^{14}\left(\mathrm{C}-24^{\circ}\right)$.

En segundo lugar, en relación a la crítica que advierte que el ejercicio de estas atribuciones constituye una suerte de "camino a la servidumbre" o "nuevo intervencionismo", no es posible dejar de señalar que hoy se evidencia la conformación de una nueva sociedad -posmoderna y globalizada-, en la que distintos actores, de una u otra manera, con su acción u omisión, crean relevantes riesgos, en los ámbitos especializados en los que se desenvuelven, que pueden derivar en importantes dańos para las personas o cosas - incluso mayores que los que amenaza, con su actuación, la misma Administración-. Lo anterior, que parece ser una verdad indiscutible, exige, por cierto, una reelaboración del concepto de Estado de Derecho y, a su vez, de los fines del Derecho Público y una completa reelaboración de sus instrumentos, puesto que hoy, para atender a este nuevo orden de cosas, no puede seguir siendo el fin y objeto de aquéllos conformar a los imperativos de esa rama del Derecho sólo a los órganos del Estado, sino que también a los particulares, en especial aquellos que, de hecho o de derecho, en este nuevo escenario, detentan formidables poderes en el seno social ${ }^{15}{ }^{16}$,

14 STC Rol No 1203 C-24ㅇ

15 En este sentido Esteve Pardo ha planteado: "en los últimos tiempos se han formado en el seno de la sociedad, al margen del Estado, unos poderes formidables, como no se habían conocido hasta ahora. Las fuerzas de la economía han abierto circuitos y formado organizaciones de muy difícil control por el Estado al que, por lo demás, llegan a conmocionar con sus movimientos. Por otro lado, el impulso tecnológico, al avanzar de manera tan trepidante y por tan diversos frentes, ha configurado unos espacios que, por su complejidad y su extensión, resultan con mucha impenetrable para los poderes públicos. Unas organizaciones al margen de las estructuras estatales tienden a imponer su dominio en esos ámbitos: las telecomunicaciones, la biotecnología, la energía la industria, los medios de comunicación; y, en no pocos casos, ese poder ni tan sólo se nuclear o articula en torno a una organización visible, sino que parece brotar súbitamente, desbordado, al extenderse una tecnología, como es el caso de internet, o al estallar un enigma de la ciencia como ocurre ahora con el genoma humano. Así es como estos poderes se constituyen y desenvuelven en muy buena medida al margen de la regulación e intervención de los poderes públicos estatales por la sencilla razón de que les resultan inaccesibles y, por ello, incontrolables" ESTEVE PARDO, José. Autorregulación. Génesis y efectos. 1era edición, Madrid, Editorial Civitas, 2002, p. 2122.

16 En este sentido Esteve Pardo ha expresado: "En cualquier caso, es ya historia la sujeción a normas jurídicas de los poderes públicos lo que, como es notorio, constituye el objetivo y la razón del ser del Estado de Derecho en el que estamos instalados. La paradoja está hoy en el problema que a ese Estado de Derecho se le plantea: no se trata ya del sometimiento a Derecho del propio Estado, sino del sometimiento a Derecho de la sociedad o de alguno formidables poderes que en ella se han formado" ESTEVE PARDO, José, Op. Cit., p. 24. Asimismo, Cantero Martínez ha señalado: "Por otro parte, hemos de tener en cuenta que el propio surgimiento del Derecho Administrativo se ha explicado tradicionalmente en la necesidad de dotar también a los ciudadanos de ciertas garantías ante el ejercicio de estas potestades (los privilegios en más y en menos de los que hablaba Rivero). Por ello, ante este nuevo fenómeno, no es de extrañar que algunos autores comiencen a plantearse la necesidad de reorientar o redimensionar el tradicional carácter garantista del Derecho Administrativo, que se ha articulado 
sana doctrina que el Tribunal Constitucional indirectamente ha hecho suya, al consagrar que la Constitución tiene fuerza imperativa incluso respecto de las relaciones entre privados -irradiación horizontal ${ }^{17}$.

Para tal cometido, como resulta evidente, el Estado tiene el deber jurídico de actuar a efectos de evitar que tales riesgos -derivados de actividades complejas y cuyo control pertenece a particulares- deriven en dańos a terceros ${ }^{18}$, deber que concreta, por una parte, normando esos sectores -o incentivando aquello, cuando por la especialidad del sector le resulta imposible, mediante la técnica de la autorregulación ${ }^{19}-\mathrm{y}$, por otro, sancionando la infracción de tal normativa, lo cual, precisamente por la marcada especialización de aquéllos, no podrían satisfactoriamente realizar los tribunales ordinarios de justicia ${ }^{20}$.

clásicamente en torno al establecimiento de las garantías necesarias frente al ejercicio del poder público en la búsqueda por la satisfacción de los intereses generales. En el momento presente, no obstante, el recurso a la autorregulación pone de manifiesto que ahora es en la propia sociedad, en los sujetos privados y no en los poderes públicos donde empiezan a residenciarse básicamente los más reveladores poderes económicos, tecnológicos, científicos, de comunicación e información, por lo que podríamos plantearnos hasta qué punto no empezaría a ser conveniente establecer esos mismos límites, esas mismas o semejantes garantías para los ciudadanos ante los nuevos sujetos que detentan estos formidables poderes" CANTERO MARTÍNEZ, Josefa. "La incidencia de la técnica y de las transformaciones sociales en el Derecho Administrativo: el recurso de la denominada "autorregulación regulada””. En: PUNZÓN MORALEDA, Jesús (Coordinador). Administraciones Públicas y Nuevas Tecnologias. 1era edición, Valladolid, Editorial Lex Nova, 2005, p. 340-342. En el mismo sentido, véase: NIETO GARCÍA, Alejandro. "Recensión al libro de Esteve Pardo: Autorregulación. Génesis y efectos", en Revista de Administración Pública, No 160, 2003, p. 429. ROMÁN CORDERO, Cristian. "Neoadministrativismo(s)", en Revista de la Asociación Internacional de Derecho Administrativo, No 4, julio-diciembre 2008, p. 266 y ss.

17 En este sentido dicha Magistratura recientemente ha afirmado: "Que el deber de los particulares y de las instituciones privadas de respetar y promover el ejercicio de los derechos consustanciales a la dignidad de la persona humana en cuanto a su existencia y exigibilidad, se torna patente respecto de aquellos sujetos a los cuales la Constitución, como manifestación del principio de subsidiariedad, les ha reconocido y asegurado la facultad de participar en el proceso que infunde eficacia a los derechos que ella garantiza. Tal es, exactamente, lo que sucede con las Instituciones de Salud Previsional, en relación con el derecho de sus afiliados a gozar de las acciones destinadas a la protección de la salud, consagrado en el artículo 19, No 9, de la Constitución;" (STC 976, C-36).

18 Cfr. DOMÉNECH PASCUAL, Gabriel. Derechos Fundamentales y Riesgos Tecnológicos. El Derecho del ciudadano a ser protegido por los poderes públicos. 1era edición, Madrid, Centro de Estudios Políticos y Constitucionales, 2006.

19 Cfr. DARNACULLETA GARDELLA, María Mercè. Autorregulación y Derecho Público: la autorregulación regulada. lera edición, Madrid-Barcelona, Marcial Pons, 2006. MUÑOZ MACHADO, Santiago, Tratado de Derecho Administrativo y Derecho Público General, 1era edición, Madrid, Civitas, 2004, I, pp. 1248 y ss.

20 En este sentido, Carretero y Carretero, han sostenido: "Los confines entre la competencia judicial y administrativa son históricos, y si bien el fondo de la cuestión puede ser penal, cuando median consideraciones de eficacia y de oportunidad, la competencia judicial exclusiva para imponer siempre y en todo caso sanciones resultaría inapropiada. $\mathrm{Si}$, en principio, la determinación de las penas es judicial, en otras ocasiones la potestad jurisdiccional del Estado, en sentido punitivo, se atribuye a la Administración como medio de coacción para obtener el cumplimiento de los deberes de los administrados" CARRETERO PÉREZ y CARRETERO SÁNCHEZ. Derecho Administrativo Sancionador. 1era edición Madrid, Edersa, 1992, p. 15. Del mismo modo, Villar Ezcurra ha planteado que: "Históricamente ha sido siempre consustancial al poder público el reconocimiento de la facultad para imponer sanciones como consecuencia de la infracción de las obligaciones o prohibiciones impuestas por el mismo poder. Se trata, simplemente, de una consecuencia lógica ya que si la facultad no existiese no podía garantizarse el cumplimiento de tales obligaciones o prohibiciones. En esencia este es el fundamento de la potestad sancionadora pero con matizaciones muy importantes a partir del constitucionalismo e implantación del Estado de Derecho. En primer lugar que la utilización de la coacción corresponde en esencia a los Tribunales de Justicia, con lo cual la potestad sancionadora de la Administración sólo podrá ser concebida como algo residual. En segundo término que, como toda potestad, debe estar reconocida por una norma y sometida en su ejercicio al Derecho" VILLAR EZCURRA, José Luis. Derecho Administrativo Especial. 1era edición, Madrid, Editorial, 
Finalmente, cabe apuntar, para alejar toda sombra de duda sobre el particular, que coincido absolutamente con lo observado por el Tribunal Constitucional de España en orden a que más inconstitucional que la aparente inconstitucionalidad de la atribución de las potestades sancionadoras de la Administración, sería así declararlo ${ }^{21}$.

\section{Los límites al ejercicio por la Administración de sus potestades sancionadoras como objeto de estudio del Derecho Administrativo Sancionador}

Cabe hacer presente que si bien defiendo, como he señalado precedentemente, tanto la constitucionalidad como la conveniencia de la atribución legal de las potestades sancionadoras a la Administración, no puedo dejar de observar, con el mismo énfasis, que necesario es que su ejercicio esté limitado dentro de contornos claros y precisos, y que fijan, primeramente, sus principios, y luego, sus reglas, estadio del que, lamentablemente, hoy lejos nos hallamos ${ }^{22}$. La razón de tal necesidad radica en que, como resulta

Civitas, 1999, p. 87. Igualmente, Ángeles de Palma del Teso ha establecido: "Parece, por tanto, que no podemos dejar de reconocer que la finalidad última del Derecho punitivo - prevenir la lesión o puesta en peligro de los bienes jurídicos que la sociedad ha decidido proteger- se alcanza de forma más efectiva dotando de potestad sancionadora a la Administración. Esta es el instrumento a través del cual el Gobierno ejerce su función ejecutiva. A la Administración interventora, propia de un Estado Social, se le han de reconocer potestades para ordenar y gestionar determinados ámbitos de la vida; y un cumplimiento eficaz de estas funciones pasa por depositar en sus manos una parte del poder punitivo del Estado. Teniendo en cuenta, además, la mayor inmediación de la Administración, en estos casos, con los hechos sancionados" DE PALMA DEL TESO, Angeles. El principio de culpabilidad en el Derecho Administrativo sancionador. 1era edición, Madrid, Editorial Tecnos, 1996, p. 37. Igualmente, Nieto ha dicho que "La potestad sancionadora de la Administración es tan antigua que como ésta misma y durante varios siglos ha sido considerada como un elemento esencial de la Policía. A partir del constitucionalismo, sin embargo, cambiaron profundamente las concepciones dominantes, puesto que el desprestigio ideológico de la Policía arrastró consigo inevitablemente el de la potestad sancionadora de la Administración, cuya existencia terminó siendo negada en beneficio de los Jueces y Tribunales, a los que se les reconocía el monopolio estatal de la represión. Los tiempos, con todo, han seguido cambiando y hoy casi nadie se atreve ya a negar la existencia de tal potestad -puesto que sería negar la evidencia-, aunque abunden los reproches nostálgicos y se abogue ocasionalmente por el mantenimiento o restablecimiento del monopolio judicial, al que se atribuye -cerrando los ojos a la realidad- el compendio de todas las perfecciones, incluidas las de la justicia, economía y eficacia" NIETO, Alejandro. Derecho Administrativo Sancionador. 3era edición, Madrid, Editorial Tecnos, 2002, p. 22.

21 En efecto, el Tribunal Constitucional de España ha planteado, en este sentido, que, "No cabe duda que en un sistema en que rigiera de manera estricta y sin fisuras la división de poderes del Estado, la potestad sancionadora debería constituir un monopolio judicial y no podría estar nunca en manos de la Administración, pero un sistema semejante no ha funcionado nunca históricamente y es lícito dudar que fuera incluso viable, por razones que no es ahora momento de exponer con detalle, entre las que se pueden citar la conveniencia de no recargar en exceso las actividades de la Administración de Justicia como consecuencia de ilícitos de menor gravedad, la conveniencia de dotar de una mayor eficacia el aparato represivo en relación con ese tipo de ilícitos y la conveniencia de una mayor inmediación de la autoridad sancionadora respecto de los hechos sancionados" (STCE de 3 de octubre de 1983). A su vez, el Tribunal Supremo de dicho país ha afirmado: "La Administración, que resignó en los Tribunales muchas de sus potestades represivas, conservó en sus manos -como seńala la doctrina- un evidente poder penal residual, al margen de teorías sobre división o separación de poderes y funciones. Nuestra norma Básica ha constitucionalizado esta potestad" (STS 8 de octubre de 1988).

22 "El problema actual no es el de la existencia de la potestad administrativa sancionadora, y ni siquiera el de su justificación, sino mucho más sencillamente -y también mucho más eficazmente- el de su juridificación. No se trata ya (en otras palabras) de devolver a los jueces potestades indebidamente detentadas por la Administración 
evidente, tales potestades son potencialmente lesivas de los derechos fundamentales del perseguido (en efecto, la sanción es, en esencia, un mal proferido a un individuo por la infracción del ordenamiento jurídico) y, en este contexto, el establecimiento de principios en los términos referidos no sólo consolidaría, en este ámbito, el Estado de Derecho ${ }^{23}$, sino que, además, (1) impediría que, en el ejercicio de tales potestades, se lesionen los derechos y garantías del perseguido ${ }^{24}$ (aunque advirtiendo desde ya que esta rama no es, en lo absoluto, como el Derecho Penal, garantismo puro), (2) evitaría un trato desigual en el ejercicio de tales potestades por distintos organismos administrativos respecto de casos análogos, y (3) desincentivaría la natural tendencia a infringir el ordenamiento jurídico cuando éste, al parecer laxo o impreciso, crea la ilusión -y no pocas veces, realidad- de que fácil es eludir la responsabilidad derivada de su contravención.

Si bien existe relativo consenso en cuanto a la necesidad de limitar tales potestades sancionadoras de la Administración, no lo existe en cuanto a determinar la intensidad de ello, problema cuya solución está estrechamente ligado a la ubicación dogmática de la rama que las estudia, siendo esencialmente dos las soluciones: o ubicarlo en el Derecho Penal o en el Derecho Administrativo. En efecto, algunos autores plantean que el Derecho Administrativo Sancionador es una rama del Derecho Penal y, por tanto, regida por los principios de este último -al modo penal-, sino por sus reglas ${ }^{25}$. Para afirmar aquello sostienen, en primer lugar, que entre la sanción administrativa y la pena existe una identidad ontológica, existiendo entre ellas tan sólo diferencias de grado o intensidad, y en segundo lugar, que tanto el Derecho Penal como el "Penal Administrativo" -como ellos llaman al Derecho Administrativo Sancionador- son manifestación de un mismo y único ius puniendi del Estado ${ }^{26}$.

sino conseguir que ésta ofrezca en su ejercicio las mismas garantías que los jueces y procesos penales. Y así, la “despenalización" de los procedimientos y garantías" NIETO, Alejandro. Op. Cit., p. 84.

23 En este sentido, Sergio Politoff ha seńalado que "Los abusos a que tales medidas -sanciones administrativaspueden conducir explica los graves reparos que suscita su utilización, sobre todo cuando ella quebranta los criterios de respeto de la dignidad y de los derechos fundamentales de la persona que deben servir de freno a los excesos del poder político. Sin embargo "si se quiere realmente un auténtico Estado de Derecho democrático", la aplicación de esas facultades -limitada a los casos permitidos por la Constitución- deberá responder de una necesidad ineludible y sujetarse a los criterios de moderación, proporcionalidad y subsidiariedad". POLITOFF LIFSCHITZ, Sergio. Derecho Penal. 2a edición, Santiago, Editorial Jurídica Conosur, 2000, p. 37-38.

24 Ya en 1960, Eduardo Novoa Monreal planteaba, describiendo este crecimiento inorgánico de las potestades sancionadoras, que "La proliferación actual de leyes penales administrativas y la mayor gravedad que gradualmente van asumiendo las sanciones que ellas establecen (las leyes sobre Pesca y Caza establecen penas privativas de libertad), hace aconsejable que el legislador se preocupe de rodear a la aplicación del Derecho Penal Administrativo de garantías semejantes a las que están incorporadas al Derecho Penal, como forma adecuada para mantener el respeto por la dignidad y los derechos del hombre" NOVOA MONREAL, Eduardo, Derecho Penal, 1960, Editorial Jurídica de Chile, Santiago, Tomo I, p.74.

25 Sobre el particular véase mi crítica a la jurisprudencia administrativa (dictamen No14.571/2005 de la Contraloría General de la República) en cuanto ha ha aplicado reglas precisas del Derecho Penal en la resolución de problemas propios del Derecho Administrativo Sancionador: ROMÁN CORDERO, Cristian. "Derecho Administrativo Sancionador: Ser o no ser. He ahí el dilema.” En: Pantoja Bauzá, Rolando (coord.). Derecho Administrativo: 120 años de cátedra. 1era edición, Santiago, Editorial Jurídica de Chile, 2008, p.135-136.

26 Véase en este sentido a ALCALDE RODRIGUEZ, Enrique. "Algunas consideraciones en torno a la identidad sustancial entre la sanción penal y la pena administrativa” En: ARANCIBIA MATTAR, Jaime y MARTINEZ ESTAY, José Ignacio. La primacía de la persona. 1era edición, Santiago, Editorial Legal Publishing, 2009, p. 795 y ss. 
Difiero abiertamente de esta posición como de sus argumentos. Para ello advierto, en cuanto al fundamento que apela a la ontología de la sanción ${ }^{27}$, que aquél análisis pertenece a la filosofía y, por tanto, resulta absolutamente ajeno a aquello que nos convoca: determinar con arreglo a qué principios o reglas jurídicas debe sujetarse el ejercicio de las potestades sancionadoras de la Administración, y en efecto, nada obsta para que, por muy idénticos que sean desde la perspectiva ontológica dos fenómenos $\mathrm{o}$ institutos, estén regidos por regímenes jurídicos distintos ${ }^{28}$. Ahora bien, en cuanto al fundamento relativo a la existencia de un único ius puniendi estatal, de tal ficción -ya que no puede calificársele de otra manera-, posible es concluir precisamente lo contrario, ya que conforme a ese razonamiento podría afirmarse que, al estar ambas ramas del Derecho informadas por los principios del Derecho Público Punitivo del Estado, a falta de precisos principios del Derecho Administrativo Sancionador, a éste debieran aplicársele los principios del primero y no los del Derecho Penal, como concluyen tales autores, o bien, por urgencia y por no haber otros principios en este orden de materias con tal grado de desarrollo ${ }^{29}$, los de este último, pero, claro está, por "regla general", es decir, con excepciones y/o con matices, según corresponda ${ }^{30}$.

Reiteradamente he sostenido que el Derecho Administrativo Sancionador es una rama autónoma del Derecho, que tiene su "anclaje" en el Derecho Público, en específico en el Derecho Administrativo, con lo cual he querido poner de relieve la finalidad prioritaria que singulariza a esta rama del Derecho, cual es la protección del interés público, sin perjuicio de otras secundarias como, por ejemplo, dotar de garantías al

27 Para la Real Academia de la Lengua ontología es: "Parte de la metafísica, que trata del ser en general y de sus propiedades trascendentales" Diccionario de la Real Academia de la Lengua Española. 21 edición, Madrid, Espasa Calpe, 1992, p. 1047.

28 En este sentido, Nieto ha planteado que "decir que dos fenómenos son iguales en la realidad no significa necesariamente que hayan de tener el mismo régimen jurídico; de la misma forma que el legislador puede dotar del mismo régimen jurídico figuras que en el mundo real son, sin duda alguna, ontológicamente diferentes" NIETO, Alejandro, Op. Cit, p. 128. Y en el mismo sentido Peman Gavín ha observado que gran parte de la doctrina "ha otorgado a cuestiones como la propia identidad sustantiva entre el delito y la infracción administrativa un carácter secundario dentro de los problemas del Derecho Sancionador, pues (...) lo esencial es determinar el concreto régimen jurídico aplicable al Derecho Sancionador". PEMAN GAVÍN, Ignacio. El Sistema Sancionador Español. Hacia una Teoria General de las Infracciones y Sanciones Administrativas. 1era edición, Barcelona, Editorial Cedecs, 2000, p. 27.

29 Así, por ejemplo, bien pueden existir responsabilidades cuya sanción importa una manifestación del ius puniendo del Estado, pero sin ser penal o administrativa, como acontece con las llamadas responsabilidades constituciones. Sobre el particular véase: Jiménez Larraín, Fernando. "Responsabilidades constitucionales." En: ASOCIACIÓN CHILENA DE DERECHO CONSTITUCIONAL, Temas Actuales de Derecho Constitucional, 1era Edición, Santiago, Editorial Jurídica de Chile, 2009, p. 119 y ss.

30 Respecto del argumento relativo al ius puniendi sostiene Nieto: "El enorme éxito de tal postura -elevada ya a la categoría de dogma incuestionable- se debe en parte a razones ideológicas, a que así se atempera el rechazo que suelen producir las actuaciones sancionadoras de la Administración, de corte autoritario, y, en parte, a razones técnicas, en cuanto que gracias a este entronque con el Derecho Público estatal se proporciona al Derecho Administrativo Sancionador un soporte conceptual y operativo del que antes carecía". Y en mismo sentido que nosotros, Nieto ha planteado: "Porque una vez integrada la potestad sancionadora de la Administración en el ius puniendi del Estado, lo lógico sería que aquélla se nutriera de la sustancia de la potestad matriz, y, sin embargo, no sucede así, sino que la potestad administrativa a quienes realmente se quiere subordinar es a la actividad de los Tribunales penales y de donde se quiere nutrir al Derecho Administrativo Sancionador es del Derecho Penal, y no del Derecho público estatal". NIETO, Alejandro, Op. Cit., p. 22. 
perseguido (cuestión que se hace más evidente cuando éste es una persona jurídica) ${ }^{31} 32$. Tesis que pareciera suscribir nuestro Tribunal Constitucional si se advierte que aquél, al referirse sobre esta cuestión, siempre ha empleado la expresión "Derecho Administrativo Sancionador" y no "Derecho Penal Administrativo" 33 .

En este contexto, cabe llamar la atención sobre la existencia de una especie de Derecho Administrativo Sancionador en el que el sujeto infractor se halla ligado a la Administración en una relación de sujeción especial, en la que, en general, es posible advertir una mayor flexibilidad en la aplicación de los principios del Derecho Administrativo Sancionador general, distinguiéndose en este aspecto el disciplinario-militar, a tal punto que la propia Constitución lo sustrae del régimen general y previene que se regirá por las normas pertinentes de sus respectivos estatutos (art. 19 No 3 inciso 2\%).

\section{El concepto de sanción administrativa como frontera del Derecho Administrativo Sancionador}

Teniendo presente que el Derecho Administrativo Sancionador se rige por especiales principios sustantivos y adjetivos, que estudiaremos en los siguientes numerales, necesa-

31 En este sentido, Nieto ha planteado: "Aquí hay, por tanto, una sustitución ilegítima que importa denunciar, y en su caso corregir, para terminar asumiendo todas las consecuencias del dogma. Imagínese, en efecto, lo que sucedería si fuera el Derecho público estatal, y no el Derecho Penal, el que inspirara al Derecho Administrativo Sancionador. El Derecho Penal, desde la perspectiva en que aquí se le contempla, es un Derecho garantista, exclusivamente preocupado por el respeto a los derechos del inculpado; mientras que en el Derecho público estatal, sin menosprecio de las garantías individuales, pasa a primer plano la protección y fomento de los intereses generales y colectivos. En otras palabras, si de veras se creyera en el dogma básico -del que verbalmente tanto se alardea-, habría que rectificar los planteamientos al uso y trasladar el Derecho Administrativo Sancionador desde los campos del Derecho Penal -donde ahora se encuentra o, al menos, quiere instalársele- a los del Derecho Público estatal. Con lo cual terminaría recuperando la potestad sancionadora de la Administración la fibra administrativa que ahora se le está negando. En definitiva, contra viento y marea hay que afirmar que el Derecho Administrativo Sancionador es, como su mismo nombre indica, Derecho Administrativo engarzado directamente en el Derecho Público estatal y no un Derecho Penal vergonzante; de la misma manera que la potestad administrativa sancionadora es una potestad ajena a toda potestad atribuida a la Administración para la gestión de los intereses públicos. No es un azar, desde luego, que hasta el nombre del viejo Derecho Penal Administrativo haya sido sustituido desde hace ańos por el más propio de Derecho Administrativo Sancionador" NIETO, Alejandro. Op. Cit. p. 26-27. Por su parte De Palma del Teso ha sostenido: "que mientras el Derecho Penal es un ámbito exclusivamente punitivo, cuya única referencia es el Derecho Público Estatal, el Derecho Sancionador Administrativo no sólo debe mirar hacia el Ordenamiendo Público Estatal, sino también hacia el propio Derecho Administrativo en el que está inserto; razón por la cual los mismos principios no tienen un contenido homogéneo en uno y otro ámbito. (...) Razones todas las vistas que justifican y exigen el recurso al Derecho Penal, por tener en él su asiento los principios aplicables a todo el Ordenamiento Punitivo, y ser referencia obligada en el proceso de elaboración de una dogmática propia del Derecho Sancionador Administrativo, teniendo en cuenta, claro está, la diferencias existentes entre los dos ámbitos y que entre ellos no existe relación de jerarquía" DE PALMA DEL TESO, Angeles. Op. Cit., p. 39-40.

32 Plantea Nieto en este sentido que "Las garantías del inculpado son ciertamente irrenunciables; pero ya no es tan cierto que tengan que proceder del Derecho Penal, puesto que el Derecho público estatal y el Derecho Administrativo están perfectamente capacitados para crear un sistema idóneo propio. Otra cosa es que hasta ahora no lo hayan hecho y que, en consecuencia, para remediar esta ausencia, haya habido, de forma provisional y urgente, que tomar a préstamo las técnicas garantistas del Derecho Penal, pero a conciencia de que no son siempre adecuadas al Derecho Administrativo Sancionador" NIETO, Alejandro, Op. Cit. p. 22 y 23.

33 Véanse al respecto las STC Nos 479 y 480 . 
rio es establecer, con cierto grado de certeza, un criterio conforme al cual distinguir qué actuación lesiva de derechos que ejecute la Administración, (entre los cuales se cuentan, v.gr., la revocación de un acto favorable, la expropiación, la imposición de medidas de coacción directa, la adopción de medidas cautelares, la imposición de multas, etcétera), pueden ser considerados, para estos efectos, una "sanción administrativa" ${ }^{4}$, pues sólo a aquéllas que tengan tal calidad pueden serle aplicables tales principios.

Llamativamente, a no ser por contadas excepciones, nuestra doctrina no ha abordado este tópico ${ }^{35}$. De ello posible es inferir que la discusión que ha habido en torno al Derecho Administrativo Sancionador, en específico sobre los principios que lo informan, ha partido del supuesto - no reconocido expresamente, por cierto- de que cualquier actuación lesiva desplegada por la Administración importa una "sanción administrativa”, produciendo con ello no sólo una hiperinflación del concepto sino que, además, una ampliación desmedida de la órbita de acción de los principios del Derecho Administrativo Sancionador, que preciso es corregir ${ }^{36}$.

En este afán, preciso es anotar, primeramente que sanción es la "consecuencia jurídica desfavorable que el incumplimiento de un deber produce respecto del obligado" ${ }^{37}$, o bien, la "pena que la ley establece para el que la infringe" 38 , en otras palabras, la garantía de cumplimiento de una norma jurídica; mas en cuanto al concepto de "sanción administrativa” no existe el mismo grado de coincidencia. Así, a modo ejemplar, se ha señalado por la doctrina que esta última es "un mal jurídico que la Administración infringe a un administrado responsable de una conducta antecedente. Son penas en

34 En este sentido el Mensaje del proyecto de ley de bases de los procedimientos administrativos sancionatorios, seńaló: "A primera vista parece del todo evidente qué es una sanción administrativa, mas como se verá a continuación son muchos los casos que parecen serlo pero que en definitiva no lo son. Cuestión que no es un mero divagar en cuestiones semánticas, pues sólo a aquello que es sanción administrativa le son aplicables los principios del derecho administrativos sancionador, sean sustanciales o procedimentales. Así, por ejemplo, la expropiación para la construcción de una carretera si es considerada sanción arrastraría consigo los principios del derecho Administrativos sancionador, es decir los principios penales con matices." En el mismo sentido se ha afirmado: "Estas garantías (las que deben respetarse al imponerse una sanción administrativa -nota nuestra-) suponen para los ciudadanos mayores derecho que los que tienen cuando se relacionan con la Administración en el seno de otro potestad (de policía por ejemplo), e implican por tanto correlativas cargas para la Administración en tanto que para no quebrantar aquéllos debe ser "más cuidadosa" que lo habitual. Es decir, así como para sancionar necesita la Administración que haya una norma con rango de ley que describa con carácter previo y suficiente detalle la infracción (principio de legalidad), que haya al menos negligencia en la actuación del sujeto (culpabilidad), que no haya pasado el tiempo que da lugar a la prescripción, que el castigo sea adecuado a las circunstancias concurrentes (proporcionalidad), que no se impongan dos castigos por un solo hecho (non bis in idem), o seguir un procedimiento donde se acrediten suficientemente los hechos partiendo de la inocencia del ciudadano, nada de lo anterior será preciso, o al menos no de un modo tanto riguroso, cuando se trate de realizar otras actuaciones que aun incidiendo en la esfera jurídica de los administrados no tengan la consideración de sanciones." (ABOGACÍA GENERAL DEL ESTADO, DIRECCIÓN DEL SERVICIO JURÍDICO DEL ESTADO. Manual de Derecho Administrativo Sancionador. 1era edición, Madrid, Editorial Thomson-Civitas, 2005, p. 111.

35 BERMÚDEZ SOTO, Jorge. "Elementos para definir las sanciones administrativas", en Revista Chilena del Derecho, Facultad de Derecho, Pontificia Universidad Católica de Chile, Número Especial, 1998, p. 323 y ss.

36 HUERGO LORA, Alejandro. Las Sanciones Administrativas. 1era edición, Madrid, Editorial Iustel, 2007, p. 187 y ss. PEMÁN GAVÍN, Ignacio. Op. Cit., p. 33 y ss.

37 COUTURE, Eduardo J. Vocabulario Jurídico. 1era edición, Montevideo, Biblioteca de Publicaciones Oficiales de la Facultad de Derecho de la Universidad de la República, 1960, p. 544.

38 Diccionario de la Real Academia de la Lengua Española, 21 edición, Madrid, Espasa Calpe, 1992, p. 1304. 
sentido técnico impuestas por la Administración, utilizando sus prerrogativas (...)"39, o bien, que es "cualquier mal infringido por la Administración a un administrado como consecuencia de una conducta ilegal a resultas de un procedimiento administrativo y con una finalidad puramente represora" ${ }^{40}$, por mencionar algunas definiciones sugeridas por la doctrina.

A mi juicio, la sanción administrativa es un concepto jurídico indeterminado, como muchos otros que pueden apreciarse en el Derecho Público (v.gr., la falta de servicio), y precisamente por ello vano es todo intento por definirla y, a su vez, peligroso, pues con ello se corre el riesgo de rigidizar en demasía su concepto, incluyendo en ella hipótesis dudosas, o bien, excluyendo otras que al parecer sí tendrían tal carácter ${ }^{41}$. Corresponde a la jurisprudencia, en consecuencia, determinar su ocurrencia en cada caso concreto y a la doctrina, a lo más, fijar sus lineamientos generales. Bajo este entendido, a continuación expondré cuatro elementos que, a mi juicio, configuran el núcleo esencial de toda "sanción administrativa":

a) La sanción administrativa debe ser impuesta por un órgano administrativo. Ciertamente la sanción administrativa debe ser impuesta por un organismo administrativo que tenga atribuida por ley facultad expresa en ese sentido. En consecuencia, no podría ser tal, por ejemplo, la medida lesiva de derechos impuesta por un organismo que no revista tal carácter, o bien, por un organismo administrativo que se ampare para ello en una norma reglamentaria, o bien, en una norma legal que sólo le confiera otras potestades, v.gr., de inspección, y no expresamente la de sancionar, por muy ligadas que a ésta estén ${ }^{42}$.

b) La sanción administrativa debe importar una lesión o menoscabo de derechos o la imposición de un deber para un particular. La sanción administrativa debe importar para el afectado un menoscabo o lesión en sus derechos o la imposición de un deber -el cual necesariamente debe estar establecido en una disposición legal-. Si la medida impuesta por un organismo administrativo carece de esta cualidad, en caso alguno podrá ser considerada "sanción administrativa".

c) La sanción administrativa debe haber sido establecida por el ordenamiento jurídico como reacción a la contravención de éste. Toda sanción administrativa debe ser, necesariamente,

CARRETERO PÉREZ y CARRETERO SANCHEZ, Op. Cit., p. 172.

40 SUAY RINCÓN, José. Sanciones Administrativas. 1era edición, Bolonia, Publicaciones del Real Colegio de España, 1989, p. 55.

${ }_{41}$ En este sentido, Huergo Lora ha señalado: "El sometimiento de las sanciones administrativas a principios y garantías penales, es decir, a un régimen jurídico específico diferente del que se aplica a otros actos de gravamen, exige identificarlas con precisión. Esa tarea no puede corresponderle al legislador, pues ello le permitiría eludir a voluntad la aplicación de las garantías establecidas por la Constitución para las sanciones. No es raro, por otro lado, que los particulares intenten extender el concepto de sanción, pidiendo a los Tribunales que reconozcan esa naturaleza a medidas que no la tienen. En el fondo late una paradoja: si ese régimen especial de las sanciones consisten en último términos en un plus de garantías que tiene como finalidad proteger a los particulares frente a medidas de efectos especialmente graves para su esfera jurídica, no se entiende que las multas, como la resolución de un contrato o la revocación de una autorización.” HUERGO LORA, Alejandro. Op. Cit., p. 186.

42 SOTO KLOSS, Eduardo. "Es tan “delgada” la línea que separa "fiscalizar” de “juzgar”, en Gaceta Jurídica, No 331,2007 , p. 35 y ss. 
la reacción frente a una acción: la realización, por acción u omisión, de una infracción administrativa, tipificada como tal, en su núcleo esencial, por ley.

d) La sanción administrativa debe ser impuesta con un solo fin: la represión o castigo de un ilícito administrativo. La sanción debe ser establecida con un solo fin: reprimir o castigar la realización de un ilícito administrativo. Si se impusiera una "sanción administrativa" con otros fines, nos hallaríamos frente a una hipótesis de desviación de poder ${ }^{43}$, que la tornaría arbitraria y que, a su vez, impediría calificarla como tal.

\section{Los principios sustantivos del Derecho Administrativo Sancionador}

Sin perjuicio de lo aseverado con anterioridad en relación a la autonomía del Derecho Administrativo Sancionador respecto del Derecho Penal, hay un hecho inobjetable: el primero, no obstante ser cada vez más extendido y lesivo, aún no tiene la solidez dogmática que se aprecia en el segundo. Frente a este estado de cosas preciso es determinar qué principios han de informar a esta incipiente rama del Derecho. Respondo esta pregunta sosteniendo que corresponde aplicar, como medida de urgencia y hasta que los principios del Derecho Administrativo Sancionador adquieran claros y precisos contornos -lo que no acontece actualmente-, como pauta y cota máxima, los principios que informan al Derecho Penal. Como pauta pues ellos, en su conjunto, establecen los lineamientos generales que deberían considerarse para tal propósito, sin que ello importe necesariamente aplicar todos y cada uno de dichos principios y con el mismo alcance que en el Derecho Penal (en otras palabras, admito la "importación", pero en caso alguno el "contrabando" de ellos) y como cota máxima, pues en la traslación de tales principios al Derecho Administrativo Sancionador, no es posible ser "más penalista que los penalistas", esto es, el alcance que en él han de tener, deberá ser siempre más flexible que en el Derecho Penal, conclusión que resulta, a todas luces, evidente si se considera que en dicha sede en caso alguno podría afectarse la libertad personal del perseguido ${ }^{44}$.

43 Sobre el particular, entre otras, véase: SILVA TAMAYO, Gustavo, Desviación de poder y abuso de derecho. 1era edición, Buenos Aires, Editorial Lexis Nexis, 2006. SANCHEZ ISAC, Jaime. La desviación de poder en los derechos francés, italiano y español. 1era edición, Madrid, Instituto de Estudios de Administración Local, 1973. CHINCHILLA MARIN, Carmen. La desviación de poder. 2a edición, Madrid, Editorial Civitas, 1999. CASTILLO BLANCO, Federico. La interpretación y aplicación del ordenamiento jurídico público. 1era edición, Madrid, Instituto Nacional de Administración Pública, 2007.

44 En el mismo sentido Nieto ha planteado que "el Derecho Administrativo Sancionador no debe ser construido con los materias y con las técnicas del Derecho Penal sino desde el propio Derecho Administrativo, del que obviamente forma parte, y desde la matriz constitucional y del Derecho Público estatal. Conste, sin embargo, que esta confesada inspiración no es consecuencia de un prejuicio ideológico, no mucho menos profesoral, sino resultado de haber constatado el fracaso de una metología -la extensión de los principios del derecho Penalque ha demostrado no ser certera desde el momento en que la traspolación automática es imposible y que las matizaciones de adaptación son tan difíciles como inseguras; hasta tal punto que el resultado final nada tiene que ver con los principios originarios, cuyo contenido tiene que ser profundamente falseado. Para rectificar este fracaso no hay más remedio que volver a empezar desde el principio y en el principio están, como he repetido, la 
En armonía con lo señalado anteriormente, el Tribunal Constitucional, a través de su sentencia $N^{\circ} 244$, de $1996^{45}$, sostuvo que tanto el Derecho Penal como el Derecho Administrativo Sancionador son manifestaciones del ius puniendi del Estado, de lo cual infieren que los principios del primero son aplicables al segundo, aunque "por regla general", esto es, conforme puede fácilmente inferirse, de forma matizada, aunque también permitiría desviaciones del esquema penal. Con ello, el Tribunal Constitucional, tácitamente reconoció la autonomía del "Derecho Administrativo Sancionador", prueba de lo cual es el empleo, hasta el día de hoy, de dicha expresión, para referirse a esta materia.

Sin perjuicio de lo anterior, a través de los fallos $\mathrm{No}_{s} 479$ y 480, de $2006^{46}$, dicha Magistratura señaló que a pesar de existir algunas diferencias entre pena y sanción, ambas son manifestación del ius puniendi del Estado, de lo cual infiere que el estatuto constitucional establecido en el $N^{\circ} 3$ del artículo 19 de la Constitución, es aplicable "con matices" al Derecho Administrativo Sancionador. Lo anterior constituye, a mi juicio, un importante cambio jurisprudencial, pues la voz "con matices", que emplean estas sentencias, es más restrictiva que la utilizada por la No 244 -"por regla general"-, ya que, a diferencia de esta última, no autorizarían desviaciones o excepciones al modelo penal, con lo cual, erróneamente, a mi juicio, el Tribunal Constitucional ha acercado el Derecho Administrativo Sancionador al Derecho Penal, poniendo con ello en entredicho su autonomía -que le es consustancial, conforme he explicado-, y ha enfatizado, a su vez, su rol garantista, en desmedro de aquél que lo singulariza: la protección del interés público.

El origen de este cambio jurisprudencial radica, al parecer, en la utilización que dicha Magistratura ha efectuado de doctrina extranjera -española- sin advertir que aquélla ha surgido a la luz de un texto constitucional sustancialmente distinto en esta materia al nuestro ${ }^{47}$. En efecto, el español, conforme previene su artículo 25, equipara la pena con

Constitución, el Derecho Público estatal y el Derecho Administrativo, por este orden. En esta tarea la presencia del Derecho Penal es no ya sólo útil sino imprescindible. El Derecho Penal ha de seguir operando, no obstante y en todo caso, como punto de referencia, como pauta técnica y, sobre todo, como cota de máxima de las garantías individuales que el Derecho Administrativo Sancionador debe tener siempre presentes" NIETO, Alejandro, Op. Cit., p. 28

45 En efecto, esta sentencia en lo medular sostuvo: "Que, los principios inspiradores del orden penal contemplados en la Constitución Política de la República han de aplicarse, por regla general, al derecho administrativo sancionador, puesto que ambos son manifestaciones del ius puniendi propio del Estado" (C-9o).

46 En lo medular estos fallos seńalaron: "Que el principio de legalidad es igualmente aplicable a la actividad sancionadora de la administración en virtud de lo prescrito en los dos últimos incisos del numeral 3 del artículo 19 de la Carta Fundamental. Aún cuando las sanciones administrativas y las penas difieren en algunos aspectos, ambas pertenecen a una misma actividad sancionadora del Estado -el llamado ius puniendi- y están, con matices, sujetas al estatuto constitucional establecido en el numeral $3^{\circ}$ del artículo 19." (C-5).

47 En este sentido se ha afirmado en relación a esta sentencia que "La pertinencia es el nexo objetivo entre el caso y las norma o principio que se toman prestado desde el ordenamiento extranjero. Un ejemplo correcto del análisis de este elementos se encuentra en el voto de los Ministros COLOMBO, VODANOVIC y CORREA (voto redactado por este último), a propósito de la asimilación del principio penal de legalidad en sede administrativosancionadora: "[l]a doctrina nacional que propugna esta asimilación ha seguido de cerca la jurisprudencia y a los autores españoles. Para jueces constitucionales no es un hecho menor anotar que en el caso español, a diferencia del chileno existe un precepto en la Carta Fundamental que sujeta a toda sanción y no sólo a las penas al principio de legalidad (artículo 25.1. del texto constitucional español). La asimilación en ese país resulta entonces obligada por 
la sanción, en cambio en el nuestro no hay una norma que le sea análoga, por mucho que algunos autores, apelando a una interpretación originaria de la Constitución, que en lo absoluto comparto, sostengan que en la Comisión de Estudio del Anteproyecto de la Constitución sí hubo conocimiento de este fenómeno y que la opinión expresa de sus integrantes fue aplicar al Derecho Administrativo Sancionador todos y cada uno de los principios del Derecho Penal, al modo penal. En otra oportunidad me he referido a lo discutido en ella $^{48} \mathrm{y}$ he llegado a concluir exactamente lo contrario, esto es, en síntesis, que si en tal Comisión se resolvió aplicar un principio de Derecho Penal al Derecho Administrativo Sancionador, ese fue el de irretroactividad de la ley sancionadora no favorable, mas no otros principios. Conclusión que resulta aun más evidente si se advierte que dicho principio -de irretroactividad de la ley sancionadora no favorable- no es exclusivo del Derecho Penal sino más bien un principio general del Derecho, tal y como lo han reconocido otros ordenamientos jurídicos ${ }^{49}$.

En este contexto, por tanto, posible es concluir, tal como lo estableció el Mensaje del Proyecto de Bases de Procedimientos Administrativos Sancionatorios ${ }^{50}$-luego retirado-, que "con las adecuaciones de rigor" son "principios sustantivos del derecho administrativo sancionador los de legalidad, irretroactividad, tipicidad, responsabilidad personal, prohibición de la privación de libertad, proporcionalidad y prescriptibilidad." ${ }^{21}$, cuyo desarrollo en el referido proyecto puede apreciarse en el Anexo de este presente trabajo.

\section{La errada aplicación que de lo señalado precedentemente han efectuado la Contraloría General de la República y los Tribunales ordinarios}

Como ha podido apreciarse, la discusión doctrinaria hasta el momento ha sido aplicar principios de Derecho Penal al Derecho Administrativo Sancionador -"por regla general" o "con matices"-, jamás ha estado referido a reglas específicas del primero. Lamentablemente, este asunto no ha sido entendido correctamente por la jurisprudencia administrativa y judicial. Es así como ambas razonando en los términos efectuados en las sentencias del Tribunal Constitucional antes citadas, no dudan no sólo en aplicar un principio de Derecho Penal al Derecho Administrativo Sancionador, sino una

el texto constitucional que la legitima (cursivas añadidas)" NUÑEZ POBLETE, Manuel A.. "Sobre "presentes griegos" e "injertos extranjerizantes". Uso y Límites de la Aplicación del Derecho No nacional en la Jurisprudencia Constitucional: El Recuso al Derecho Comparado". En: ARANCIBIA MATTAR, Jaime y MARTÍNEZ ESTAY, José Ignacio (coord.), La Primacía de la Persona. 1era. Edición, Editorial Legal Publishing, Santiago, 2009, p. 1154 y 1155.

48 Véase: ROMÁN CORDERO, Cristian. "Derecho Administrativo Sancionador: Ser o no ser. He ahí el dilema.", Op. Cit., p. 132 y ss.

49 Así, por ejemplo, el artículo 9.3. de la Constitución española señala: "La Constitución garantiza (...) la irretroactividad de las disposiciones sancionadoras no favorables".

50 Boletín No 3475-06.

51 Mensaje de SE el Presidente de la República con el que se inicia un proyecto de ley que establece las bases de los procedimientos administrativos sancionatorios (Mensaje 541-350), p. 14. 
regla precisa contenida en el Código del ramo. Con ello se verifica uno de los grandes temores de Alejandro Nieto, que la importación de principios penales degenere en el contrabando de reglas, al Derecho Administrativo Sancionador.

Ello ha acontecido a propósito de la prescripción. Ciertamente que en el Derecho Administrativo Sancionador ha de regir el principio de prescripción de la responsabilidad administrativa. El problema se suscita cuando, para un caso determinado, el ordenamiento jurídico no dispone de una regla precisa de prescripción. ¿¿Cuál debe aplicarse? La Contraloría ha resuelto aplicar la norma de las faltas penales contenida en el artículo 94 del Código Penal, de seis meses ${ }^{52}$, planteamiento que ha seguido recientemente la Corte Suprema ${ }^{53}$, ambos en materia de derecho administrativo sancionador eléctrico ${ }^{54}$.

No comparto lo resuelto por la Contraloría General de la República y por la Corte Suprema, ya que importa aplicar reglas penales al Derecho Administrativo Sancionador, con lo que indebidamente es "penalizado". Ahora bien, estimo que la solución acertada tampoco es aquella que plantea el voto de minoría del referido fallo de la Corte Suprema, redactado por don Pedro Pierry Arrau, esto es, aplicar las normas del Código Civil (en específico el art. 2515), que establece la prescripción general de cinco años, pues, a mi juicio, dicho Código no tiene el carácter supletorio en materias de Derecho Administrativo ${ }^{55}$, y menos aún en materias de orden punitivo como lo es la prescripción de la responsabilidad administrativa. Sostengo que los propicio habría sido aplicar algunas de las reglas que regulan la prescripción en otros sectores del Derecho Administrativo Sancionador, v.gr., aquélla que regula esta materia en el Derecho Administrativo Sancionador tributario (tres años), disciplinario (cuatro ańos), etcétera.

Véase nota No 24

53 Se trata de la sentencia de la Corte Suprema Rol 3283-2009, de 3 de agosto de 2009, que en lo medular sostuvo: "Tercero: Que ante la ausencia de norma expresa en el ordenamiento citado, y tratándose de disposiciones especiales, debe entenderse que en lo no contemplado expresamente en ellas, deben aplicarse supletoriamente las reglas del derecho común que, según la materia específica, correspondan. En este caso, el derecho común aplicable es el Derecho Penal, manifestación del mismo ius puniendi estatal, específicamente su artículo 94, pues en la especie, resulta evidente que el procedimiento infraccional persigue la sanción de una falta, en este caso, por infracción al ordenamiento administrativo, y por tanto, debe darse esa calificación a los hechos denunciados.

Dicho precepto dispone que, respecto de las faltas, la acción prescribe en seis meses, tiempo que se cuenta desde la comisión del hecho respectivo, y que para el caso de la sanción administrativa habrá de contarse desde que la autoridad administrativa tomó conocimiento o, razonablemente, debió haberlo tomado. En efecto, el plazo para la extinción de las infracciones administrativas sólo podrá comenzar desde esa última data, toda vez que a partir de ese momento la Superintendencia de Electricidad y Combustibles podía ejercer sus atribuciones fiscalizadoras en el cumplimiento de la normativa eléctrica;"

54 Véanse los artículos 15 y siguientes de la Ley No 18.410, orgánica de la Superintendencia de Electricidad y Combustibles.

55 Coincido con los planteado por Vergara Blanco en cuanto a que "Existió en el origen de las normas administrativas un aporte de instituciones y principios del derecho civil con los ajustes del caso; pero hoy no cabe postular el "trasvase" directo de normas de naturaleza civil para integrar el orden normativo administrativo, en el caso en el que este ofrezca "lagunas" VERGARA BLANCO, Alejandro. "Derecho Administrativo y supuesta supletoriedad del Código Civil”. En: ARANCIBIA MATTAR, Jaime y MARTINEZ ESTAY, José Ignacio (coord.). La Primacía de la Personal. 1era edición, Santiago, Editorial Legal Publishing, 2009, p. 280. 


\title{
6. Los principios adjetivos del procedimiento administrativo sancionador (el debido procedimiento administrativo sancionador)
}

\author{
Supletoriedad de la Ley $N^{\circ}$ 19.880, sobre Bases de los Procedimientos \\ Administrativos, en relación a los procedimientos administrativos \\ sancionatorios
}

Desde ya es preciso evitar un equívoco: sostener que la aplicación supletoria de la ley No 19.880, sobre Bases de los Procedimientos Administrativos, a los procedimientos administrativos sancionatorios, da plena satisfacción a la garantía constitucional del justo y racional procedimiento. Es a mi juicio un error, pues si bien respecto de estos procedimientos dicha ley sí tiene aplicación supletoria, no puede entenderse que se satisfaga el mandato constitucional del debido proceso, pues para ello se requiere un plus que representan las garantías propias del procedimiento penal transplantadas siempre de forma aminorada al procedimiento administrativo sancionador, que no consulta o bien no con la intensidad suficiente para dar cumplimiento a tal mandato, el procedimiento administrativo común.

\section{Características del debido procedimiento sancionador administrativo}

La Administración, en el ejercicio de sus potestades sancionadoras, debe siempre y en todo caso conformarse a un procedimiento idóneo que satisfaga debidamente los imperativos del justo y racional procedimiento, en los términos señalados en el artículo 19 No 3 de la Constitución ${ }^{56}$. Así, por ejemplo, el Tribunal Constitucional ha expresado, a propósito del ejercicio por la Administración de las referidas potestades, al controlar preventivamente algunos proyectos de ley, que se infringe el artículo 19 No 3 "porque no establece normas que le aseguren a quien resulte afectado por la resolución del Director del Servicio Electoral un justo y racional procedimiento, ya que no contempla entre otras garantías, ni el emplazamiento a la persona respectiva, ni la oportunidad para defenderse ni tampoco la posibilidad de deducir recurso alguno ante otra autoridad para reclamar de una eventual cancelación indebida" ${ }^{27}$, o bien que "ineludible conclusión de que él infringe los incisos $1^{\circ}$ y $5^{\circ}$ del No 3 del artículo 19 de la Carta Fundamental, porque no establece normas que aseguren al

56 En idéntico sentido Aguerrea Mella ha sostenido: "Asimismo, con ello se ratifica lo sostenido por la mejor doctrina nacional en cuanto a que en los procedimientos administrativos, cualesquiera que sean, es enteramente aplicable el art. 19 No 3 de la Constitución y que las decisiones que emitan los órganos de la Administración deben basarse en un proceso previo legalmente tramitado, correspondiéndole al legislador contemplar los elementos que lo hagan racional y justo." AGUERREA MELLA, Pedro. "Límites procesales a las potestades sancionadoras de la Administración en la jurisprudencia del Tribunal Constitucional”. En: Sanciones Administrativas y Derechos Fundamentales, Regulación y Nuevo intervencionismo. 1era edición, Santiago, Conferencias Santo Tomás de Aquino, 2005, p. 96.

57 Sentencia Rol No 38 C- $24^{\circ}$ 
partido político en formación que resulte afectado un justo y racional procedimiento, ya que no contempla ni el emplazamiento de dicho partido en formación ni tampoco la oportunidad para defenderse" 58

\section{Debido proceso penal y debido procedimiento administrativo sancionador}

En el plano sustantivo, se ha señalado que al Derecho Administrativo Sancionador se le aplican los principios del Derecho Penal, por regla general, esto es, con excepciones y atenuaciones. Ahora bien, en el plano adjetivo o procedimiental puede sostenerse, de forma análoga, que se aplican al Derecho Administrativo Sancionador, los principios propios del Derecho Procesal Penal, claro está que con el mismo alcance.

En este sentido, el Tribunal Constitucional español ha afirmado: "La declaración de responsabilidad penal se efectúa en un proceso en el que rigen garantías específicas integradas en el derecho a un proceso con todas las garantías (art. 24.2 CE) que repercuten en el contenido del derecho a la presunción de inocencia, mientras que la declaración de responsabilidad por infracción administrativa se realiza en un procedimiento en el que tal derecho se aplica de forma modalizada, lo que implica un menor contenido garantista del mismo (...)."

\section{Principios adjetivos del Derecho Administrativo Sancionador}

Estos principios de orden procedimental que informan al Derecho Administrativo Sancionador pueden desglosarse, sintéticamente, de la siguiente manera:

\section{1). Derecho al procedimiento administrativo sancionador.}

La imposición de una sanción administrativa debe siempre ser el resultado de un procedimiento idóneo seguido por un organismo administrativo. No resulta constitucionalmente admisible, en consecuencia, aun cuando una norma legal así lo permita expresamente-la que de existir no dudaría en tachar de inconstitucional-, la imposición de tales sanciones "de plano". En este sentido, el Tribunal Constitucional, a propósito del procedimiento disciplinario seguido en contra de un juez, ha resuelto: "Que, en consecuencia, aun cuando se trate de un "resolver de plano" con las características antes indicadas, esta Magistratura concluye que resultaría contrario a un procedimiento racional y justo que la Corte de Apelaciones proceda de este modo, sin relación pública ni escuchar ella misma a la parte afectada al decidir los cargos que se formulan en contra de la requirente, pues lo que debe decidir en la gestión pendiente es una cuestión trascendente, no sólo para derechos esenciales de la requirente, sino también 
y especialmente delicada para la independencia de la que debe gozar un secretario cuando, obrando como juez subrogante, dicta una sentencia definitiva." ${ }^{59}$.

\section{2) Reserva de ley del procedimiento administrativo sancionador}

No basta la existencia de un procedimiento sancionador administrativo, necesario es que aquél esté consultado en una norma de rango legal. En todo caso, esto no quiere decir de antemano que se impida la colaboración de normas infralegales para tal cometido (v.gr., reglamento y auto acordados -en materia disciplinaria-judicial), ya que aquello posible es, a mi juicio, siempre que la ley haya reglado los aspectos sustantivos del procedimiento administrativo sancionador $y$ tales normas lo precisen sin restringir los derechos y garantías del perseguido.

En este sentido el Tribunal Constitucional ya ha observado, en relación a un proyecto de ley que remitía el establecimiento del procedimiento sancionador a normas infralegales, que habiéndose constatado la "omisión de toda norma regulatoria del proceso y procedimiento a través del cual pueden ser impuestas aquellas sanciones, contemplando la defensa de rigor, entre otras situaciones constitucionalmente anómalas", no es posible sino concluir que "las omisiones normativas que evidencia ese precepto en formación impiden que pueda considerarse cumplido el cúmulo de exigencias previstas en el artículo 19 No 3 de la Constitución. Consiguientemente, el Tribunal debe declarar que tal disposición del proyecto infringe el fondo del precepto constitucional señalado, reproche de inconstitucionalidad material que así será decidido en la parte resolutiva de esta sentencia." ${ }^{60}$.

3) El procedimiento sancionador administrativo debe satisfacer las exigencias de un justo y racional procedimiento

El procedimiento administrativo sancionador debe satisfacer la garantía de un justo y racional procedimiento, lo que exige que aquél consulte una serie de derechos y garantías para el perseguido en dicha sede, insertos en el concepto de debido proceso, en especial:

a) Derecho a la defensa jurídica

En este sentido el Tribunal Constitucional ha aseverado: "Que, de lo razonado en los considerandos precedentes, fluye que los principios del artículo 19 No 3 de la Constitución, en la amplitud y generalidad ya realzada, se aplican, en lo concerniente al fondo o sustancia de toda diligencia, trámite o procedimiento, cualquiera sea el órgano estatal involucrado, trátese de actuaciones judiciales, actos jurisdiccionales o decisiones administrativas en que sea, o pueda ser, afectado el principio de legalidad contemplado en la Constitución, o los derechos asegurados en el artículo 19 No 3

\footnotetext{
STC Rol No 747, C-11\%.

STC Rol No 437, C- $22^{\circ}$ y $23^{\circ}$
} 
de ella, comenzando con la igual protección de la ley en el ejercicio de los atributos fundamentales. Además y de los mismos razonamientos se sigue que los principios contenidos en aquella disposición constitucional rigen lo relativo al proceso racional y justo, cualquiera sea la naturaleza, el órgano o el procedimiento de que se trate, incluyendo los de índole administrativa, especialmente cuando se ejerce la potestad sancionadora o infraccional. Por consiguiente, el legislador ha sido convocado por el Poder Constituyente a ejercer su función en plenitud, esto es, tanto en cuestiones sustantivas como procesales, debiendo en ambos aspectos respetar siempre lo asegurado por la Carta Fundamental en el numeral referido;" 61

b) Derecho de presunción de inocencia

En este sentido el Tribunal Constitucional ha establecido -en relación a la responsabilidad penal, pero aplicable igualmente, "por lo general", a la responsabilidad administrativa-: "la prohibición de presumir de derecho la responsabilidad penal constituye "un principio que es concreción de la dignidad de la persona humana, consagrada como valor supremo en el artículo $1^{\circ}$ de la Constitución Política, y del derecho a la defensa en el marco de un debido proceso, en los términos que reconoce y ampara el artículo 19 No 3 de la Ley Fundamental", como esta Magistratura sentenció en fallo recaído sobre la causa Rol No 519-2006. Acercándonos a la especie, la prohibición seńalada representa un soporte sustancial a gran parte de las garantías de la doctrinariamente bien llamada igualdad ante la justicia que en nuestro ordenamiento adoptó la peculiar denominación "igual protección de la ley en el ejercicio de sus derechos", dando sustento a la presunción de inocencia en materia penal, de unánime reconocimiento doctrinario, legislativo y jurisprudencial;" 62

c) De acceso a la justicia

En este sentido el Tribunal Constitucional ha establecido: "No se repetirán aquí los razonamientos que, en las sentencias referidas, han fundado tal conclusión, la que además parece evidente: el derecho de acceso a la justicia forma parte de la igual protección de la ley en el ejercicio de los derechos y del derecho al debido proceso, consagrado por la Constitución." ${ }^{63}$

A tales derechos, a la luz del derecho comparado, podemos agregar: el derecho a ser informado de la acusación, el derecho a no declarar contra sí mismo y a no confesarse culpable, el derecho a la defensa y a la asistencia de letrado, el derecho a la prueba (a allegarla e impugnarla), el derecho a la presunción de inocencia (en relación, especialmente, a la prueba válida, a la carga de la prueba, a la valoración de la prueba, valor de los actas de inspección y atestados policiales o de funcionarios ministros de fe $\mathrm{y}$ como regla de tratamiento), etcétera ${ }^{64}$.

\footnotetext{
STC Rol No 437, C-17 En el mismo sentido se han pronunciado las sentencias Rol Nos 389 C-13 y 376 $\mathrm{C}-35^{\circ}$. 


\section{La inspección administrativa como antesala del procedimiento administrativo sancionador y su sujeción a los imperativos del debido proceso}

Previo al inicio del procedimiento administrativo sancionador, la Administración puede efectuar inspecciones, en las que puede recabar medios de prueba conforme a los cuales formular cargos dentro de dicho procedimiento. Cabe preguntarse, entonces, si dicha inspección administrativa ${ }^{65}$, entendida como antesala del procedimiento administrativo sancionador, debe conformarse, del mismo modo, al imperativo del justo y racional procedimiento.

El Tribunal Constitucional ha dado una respuesta afirmativa a la pregunta planteada y, en efecto, ha señalado que "toda sentencia de un órgano que ejerza jurisdicción se funde en un proceso previo legalmente tramitado exigiendo al legislador que garantice un racional y justo procedimiento. Es decir, lo que la disposición prescribe es que una vez establecido por el legislador un proceso legal éste debe cumplir además con las cualidades de racional y justo. En el caso en análisis no se cumple y se infringe el precepto constitucional anteriormente referido, pues el artículo 16, en su inciso tercero, otorga facultades a un servicio para que efectúe actuaciones de índole jurisdiccional, pero no se detalla ni se precisa en forma exhaustiva, al igual como lo hace el Código de Procedimiento Penal, para garantizar eficazmente los derechos de las personas, el procedimiento a que se debe someter dicho servicio con las facultades que se le otorgan. Es especialmente grave e ilegítimo, entre otros, que no se señale plazo a la investigación; la oportunidad y número de veces que las medidas pueden decretarse y realizarse; el no contemplar la asistencia de abogado defensor y no otorgar recursos ordinarios o especiales para objetarlas, etc." ${ }^{66}$

Del mismo modo la doctrina comparada ha expresado: "Si, como hemos advertido antes, la inspección es una actividad material que no constituye propiamente un procedimiento administrativo, las actuaciones que la integran no habrán de respetar sus principios. Desde luego, no resultará exigible trasladar automáticamente la integridad de las garantías procedimentales a dicho ámbito. Este se complica, sin embargo, porque la actuación inspectora puede descubrir irregularidades contra las que haya que adoptar medidas de reacción. Sobre todo, porque puede descubrir la comisión de infracciones (administrativas o penales) que, generalmente, darán origen a la tramitación de un procedimiento administrativo sancionador o un proceso penal; $y$, especialmente, porque, con ciertos requisitos y limitaciones, lo descubierto por el inspector y debidamente reflejado en sus actas puede valer, si se incorpora al expediente sancionador con las debidas garantías, como prueba de la acusación para sancionar. Es decir, en la medida

sancionador y los derechos fundamentales. 1era Edición, Madrid, Thomson Civitas, 2008.

65 Sobre el particular, revísese: GARCIA URETA, Agustín, La Potestad Inspectora de las Administraciones Públicas, Editorial Marcial Pons, Madrid 2006. RIVERO ORTEGA, Ricardo, El Estado Vigilante. Consideraciones Jurídicas sobre la Función Inspectora de la Administración, Editorial Tecnos, Madrid 2000.

66 STC Rol No 198 C-10º. 
en que el resultado de la acción inspectora puede afectar a procedimientos posteriores y comprometer las posibilidades de defensa, sí cabrá anticipar parcialmente algunas formalidades similares a las del procedimiento, con el propósito de que las actuaciones que la integran no se conviertan, en la práctica, en una instrucción prematura y sin garantías de los expedientes sancionadores ulteriores." ${ }^{67}$

\section{Conclusiones}

1. El Derecho Administrativo Sancionador no es un apéndice del Derecho Penal, sino que, muy por el contrario, es una rama autónoma del Derecho, "anclada" en el Derecho Público, en específico en el Derecho Administrativo, y que, por ello, sirve un rol prioritario, cual es, resguardar el interés público.

2. La sanción administrativa es un concepto jurídico indeterminado que el juez deberá precisar en cada caso concreto. Sin perjuicio de ello, posible es establecer algunas características que configuran lo que he denominado su núcleo esencial: a) debe ser impuesta por un organismo administrativo, b) debe importar para el infractor una lesión, o bien, la imposición de un deber, c) debe ser consecuencia inequívoca de la comisión de una infracción administrativa, y d) debe ser impuesta con un sólo fin: la represión o el castigo.

3. No obstante su autonomía, ante la inexistencia de un cuerpo dogmático sólido en cuanto a sus principios sustantivos, por razones de urgencia, deben serle aplicados, como pauta y cota máxima, aquellos que informan al Derecho Penal, pero, claro está, que con excepciones o matizaciones, según corresponda.

4. Por otra parte, en el plano adjetivo o procedimental, la Administración, en el ejercicio de estas potestades, igualmente, deberá observar todos aquellos principios que deriven de la garantía del justo y racional proceso penal, con excepciones o matizaciones. Entre ellos se cuentan el derecho a la defensa jurídica, a la presunción de inocencia y al acceso a la justicia.

\section{Bibliografía}

Abogacía general del estado y dirección del servicio jurídico del estado. Manual de Derecho Administrativo Sancionador. lera edición, Madrid, Editorial ThomsonCivitas, 2005.

Aguerrea Mella, Pedro. "El estatuto constitucional de la penas. Su aplicación a las sanciones administrativas conforme a los antecedentes de la Comisión de Estudio 
de la Nueva Constitución.” En: Sanciones Administrativas y Derechos Fundamentales, Regulación y Nuevo Intervencionismo. lera edición, Santiago, Conferencias Santo Tomás de Aquino, 2005.

Aguerrea Mella, Pedro. "Límites procesales a las potestades sancionadoras de la Administración en la jurisprudencia del Tribunal Constitucional." En: Sanciones Administrativas y Derechos Fundamentales, Regulación y Nuevo intervencionismo. 1era edición, Santiago, Conferencias Santo Tomás de Aquino, 2005.

Alarcón Sotomayor, Lucía. El Procedimiento Administrativo Sancionador y los Derechos Fundamentales. 1era edición, Madrid, Thomson-Civitas, 2007.

Alcalde Rodríguez, Enrique. "La personalidad jurídica y el poder sancionador de la Administración", en Revista Actualidad Jurídica, Universidad del Desarrollo, $\mathrm{N}^{\circ}$ 1, enero 2000, p. 183 y ss.

Alcalde Rodríguez, Enrique. "Bienes Jurídicos protegidos y potestad sancionadora de la Administración." En: Sanciones Administrativas y Derechos Fundamentales, Regulación y Nuevo intervencionismo. 1era edición, Santiago, Conferencias Santo Tomás de Aquino, 2005.

Alonso Madrigal, Francisco Javier. Legalidad de la Infracción Tributaria (Reserva de ley y tipicidad en el Derecho Tributario Sancionador). 1era edición, Madrid, Dykinson, 1998.

Arancibia Mattar, Jaime. "Control judicial de sanciones administrativas en materia económica. Notas para un análisis crítico del caso británico." En: Sanciones Administrativas y Derechos Fundamentales, Regulación y Nuevo intervencionismo. 1era edición, Santiago, Conferencias Santo Tomás de Aquino, 2005.

Aróstica Maldonado, Iván. "Algunos Problemas del Derecho Administrativo Penal”, en Revista de Derecho, Universidad de Concepción, N 182, 1987, p. 71 y ss.

Aróstica Maldonado, Iván. "El Derecho Administrativo Sancionador y la Proporcionalidad de los Actos Administrativos", en Revista de Derecho y Jurisprudencia, Tomo LXXXIV, 1987, p. 109 y ss.

Aróstica Maldonado, Iván. "Un Lustro de Sanciones Administrativas (1988-1992)", en Revista de Derecho Público, Facultad de Derecho de la Universidad de Chile, No 50, p. 173 y ss.

Aróstica Maldonado, Iván. "Sanciones administrativas y prescripción." En: Sanciones Administrativas y Derechos Fundamentales, Regulación y Nuevo intervencionismo, lera edición, Santiago Conferencias Santo Tomás de Aquino, 2005.

Avilés Hernández, Víctor Manuel. "Algunas Consideraciones Constitucionales relativas al Orden Público Económico y el Derecho Penal”, en Revista de Derecho Público, No 62, 2000, p. 169 y ss.

Bajo, Miguel, y Bacigalupo, Silvina. Derecho Penal Económico, Madrid, Editorial 
Centro de Estudios Ramón Areces, 2001.

Bermúdez Soto, Jorge. "Elementos para definir las sanciones administrativas", en Revista Chilena del Derecho, Número Especial, 1998, p. 323 y ss.

Calvo Charro, María. Sanciones Medioambientales. 1era edición, Madrid, Editorial Marcial Pons, 1999.

Carnevali Rodríguez, Raúl. Derecho penaly derecho sancionador en la Unión Europea. Granada, Editorial Comares, 2001.

Cobo Olvera, Tomás. El procedimiento administrativo sancionador tipo. Barcelona, Editorial Bosch, 2001.

De Palma Del Teso, Angeles. El principio de culpabilidad en el Derecho Administrativo Sancionador. Madrid, Editorial Tecnos, 1996.

Dellis, George. Droit Pénal et Droit Administratif. La influence des principes du droit penal sur le droit administratif répressif. París, Libraire Génerale de Droit et de Jurisprudence, 1997.

Evans Espiñeira, Eugenio. Derecho Eléctrico. 1era edición, Santiago, Editorial Lexis Nexis, 2003.

Evans Espiñeira, Eugenio. “Los tipos penales administrativos en la Ley 18.410, orgánica de la Superintendencia de Electricidad y Combustibles", en Revista de Derecho Administrativo Económico de Recursos Naturales, Vol III/N 3 , octubre-diciembre 2001, p. 637 y ss.

Garberí Llobregat, José y Buitrón Ramírez, Guadalupe. El Procedimiento Administrativo Sancionador, Valencia. Editorial Tirant Lo Blanch, 2001.

García De Enterría, Eduardo. "El problema jurídico de las sanciones administrativas", en Revista Española de Derecho Administrativo, No 10, 1976, p. 409 y ss.

Huergo Lora, Alejandro. Las Sanciones Administrativas. 1era edición, Madrid, Editorial Iustel, 2007.

Lesmes Serrano, Carlos, y otros. Derecho Penal Administrativo (Ordenación del Territorio, Patrimonio histórico y Medio Ambiente). Granada, Editorial Comares, 1997.

Maljar, Daniel E.. El Derecho Administrativo Sancionador. 1era edición, Buenos Aires, Editorial Ad-Hoc, 2004.

Mendoza Zúñiga, Ramiro y Oddo Beas, Blanca. "Del recurso de reposición administrativo y su aplicación ante la ley especial (el caso de la legislación de telecomunicaciones)", en Revista Actualidad Jurídica N 8, julio 2003, p. 286.

Mendoza Zúñiga, Ramiro. "Acerca del principio general de intransmisibilidad de las multas y en particular cuando ellas no se encuentran ejecutoriadas." En: Sanciones Administrativas y Derechos Fundamentales, Regulación y Nuevo intervencionismo, lera edición, Santiago, Conferencias Santo Tomás de Aquino, 2005.

Meseguer Yebra, Joaquín. El principio "non bis in idem” en el procedimiento administrativo sancionador. 1era edición, Barcelona, Editorial Bosch, 2000. 
Meseguer Yebra, Joaquín. La Tipicidad de las Infracciones en el Procedimiento Administrativo Sancionador, 1era edición, Barcelona, Editorial Bosch, 2001.

Navarro Beltrán, Enrique. "Notas sobre Potestad Sancionatoria de la Autoridad Administrativa y Principio de Legalidad", en Revista de Derecho Público, $\mathrm{N}^{\circ}$ 67, p. 118 y ss.

Nieto García, Alejandro. Derecho Administrativo Sancionador. 3era edición, Madrid, Editorial Tecnos, 2002.

Orena Domínguez, Aitor. Infracciones y Sanciones Tributarias: un Estudio Jurisprudencial. Bilbao, Servicio Editorial Universidad del País Vasco, 2002.

Peman Gavín, Ignacio. El Sistema Sancionador Español. Hacia una Teoría General de las Infracciones y Sanciones Administrativas. Barcelona, Editorial Cedecs, 2000.

Quirós Lobos, José María. Principios de Derecho Sancionador. Granada, Editorial Comares, 1996.

Retortillo, Martín, "Multas administrativas", en Revista Administración Pública, $\mathrm{N}^{\circ} 71$.

Rosini, Emilio. Sanzioni administrative. Milano, Giuffrè Editore, 1991.

Román Cordero, Cristian. "Derecho Administrativo Sancionador: Ser o no ser. He ahí el dilema." En: Pantoja Bauzá, Rolando (coord.). Derecho Administrativo: 120 años de cátedra. lera edición, Santiago, Editorial Jurídica de Chile, 2008, p. 107 y ss.

Román Cordero, Cristian, "Los principios del Derecho Administrativo Sancionador Chileno", en Revista de Derecho Público, No 69, I, p. 24 y ss.

Román Cordero, Cristian. "Neoadministrativismo(s)", en Revista de la Asociación Internacional de Derecho Administrativo, No 4, p. 263 y ss.

Román Cordero, Cristian. "El castigo en el Derecho Administrativo", en Revista de Derecho y Humanidades (en prensa).

Santamaría Pastor, Juan Alfonso. Principios de Derecho Administrativo. 3era edición, Madrid, Editorial Centro de Estudios Ramón Areces, Vol II, 2002.

Sanz Gandasegui, Francisco. La potestad sancionatoria de la administración: la Constitución española y el Tribunal Constitucional. Madrid, Edersa, 1985.

Soto Kloss, Eduardo. "Notas para el estudio de la potestad sancionadora de la Administración", en Boletín de Investigaciones, Facultad de Derecho, Pontificia Universidad Católica de Chile, Nos 44 y 45, 1979/1980, p. 95 y ss.

Soto Kloss, Eduardo. "La impugnación de sanciones administrativas y el derecho fundamental de acceso a la justicia. El "solve et repete" y el Estado de Derecho". En: Sanciones Administrativas y Derechos Fundamentales, Regulación y Nuevo intervencionismo. 1era edición, Santiago, Conferencias Santo Tomás de Aquino, 2005.

Soto Kloss, Eduardo. "La potestad sancionadora de la Administración, ¿̇e adecua a la Constitución?". En: Sanciones Administrativas y Derechos Fundamentales, Regulación y Nuevo intervencionismo. 1era edición, Santiago, Conferencias Santo 
Tomás de Aquino, 2005.

Soto Kloss, Eduardo. "Es tan "delgada" la línea que separa "fiscalizar" de "juzgar", en Gaceta Jurídica, No 331, 2007, p. 35 y ss.

Téllez Aguilera, Abel. Seguridady disciplina penitenciaria. Un estudio jurídico. Madrid, Edisofer, 1998.

Trayter Jiménez, Juan Manuel y AGUADO I CUDOLA, Vicenc. Derecho Administrativo Sancionador: Materiales. Barcelona, Editorial Cedecs, 1995.

Trayter Jiménez, Juan Manuel. Manual de derecho disciplinario de los funcionarios públicos. Madrid, Marcial Pons, 1992.

Vergara Blanco, Alejandro. Derecho Eléctrico. 1era edición, Santiago Editorial Jurídica, 2004.

Vergara Blanco, Alejandro. "Esquema de los principios del Derecho Administrativo Sancionador", en Revista de Derecho, Universidad Católica del Norte, Vol $11 \mathrm{~N}^{\circ}$ 2 (2004), p. 142.

Zornoza Pérez, Juan. El sistema de infracciones y sanciones tributarias (Los principios constitucionales del derecho sancionador). Madrid, Editorial Civitas, 1992.

\section{Anexo. Proyecto de ley de bases de los procedimientos administrativos sancionatorios (Boletín No 3475-06).$$
\begin{array}{llllllllllllll}
\mathbf{P} & \mathbf{R} & \mathrm{O} & \mathrm{Y} & \mathrm{E} & \mathrm{C} & \mathrm{T} & \mathrm{O} & \mathrm{D} & \mathrm{E} & \text { L } & \text { E } & \text { Y: }
\end{array}
$$

“ARTÍCULO 1.- Apruébase la siguiente Ley de Bases de los Procedimientos Administrativos Sancionatorios:

\section{“TITULO I}

\section{Disposiciones generales}

Artículo 1\%.- La presente ley establece y regula las bases de los procedimientos administrativos para el ejercicio de la potestad sancionatoria atribuida a los órganos de la Administración del Estado. En caso que la ley establezca procedimientos sancionatorios especiales, el procedimiento previsto en la presente ley se aplicará con carácter supletorio.

Artículo $2^{\mathbf{o}}$.- Los actos administrativos que se originen en procedimientos sancionatorios se regirán, en lo pertinente, por las normas contenidas en los Capítulos I, III y IV de la Ley No 19.880, sobre Bases de los Procedimientos Administrativos.

La toma de razón de los actos administrativos que se originen en procedimientos sancionatorios se regirá por lo dispuesto en la Constitución y en la Ley Orgánica Constitucional de la Contraloría General de la República. 
Artículo 30.- Las disposiciones de la presente ley serán aplicables a los ministerios, las intendencias, las gobernaciones y a los servicios públicos creados para el cumplimiento de la función administrativa. También se aplicarán a la Contraloría General de la República, a las Fuerzas Armadas y a las de Orden y Seguridad Públicas, a los gobiernos regionales y a las municipalidades.

Las referencias que esta ley haga a la Administración o a la Administración del Estado, se entenderán efectuadas a los órganos y organismos señalados en el inciso precedente.

\section{TITULO II}

Del ejercicio de la potestad sancionadora

Artículo 40.- El ejercicio de la potestad sancionadora corresponde a los órganos de la administración que la tengan atribuida por disposición de rango legal o reglamentario.

Artículo $5^{\circ}$.- El ejercicio de la potestad sancionadora se sujetará a las disposiciones vigentes en el momento de producirse los hechos que constituyan la infracción administrativa.

No obstante, siempre que las nuevas disposiciones sancionadoras favorezcan al presunto infractor, éstas se aplicarán con efecto retroactivo desde el momento de su entrada en vigencia.

Artículo 60.- Sólo constituyen infracciones administrativas las vulneraciones del ordenamiento jurídico previstas como tales en la ley y en los reglamentos dictados conforme a ella o en el reglamento.

La comisión de infracciones administrativas establecida mediante el procedimiento legal, sólo originará las sanciones previstas en la ley o en el reglamento.

Para los efectos de la graduación de la sanción, las infracciones administrativas que no tengan señalada una clasificación en la ley, se clasificarán en leves, graves y muy graves.

Las disposiciones que definan infracciones y sanciones administrativas no serán susceptibles de aplicación analógica.

Artículo 70.- Sólo podrán ser sancionadas por hechos constitutivos de infracción administrativa, las personas naturales y jurídicas que resulten responsables de los mismos en el respectivo procedimiento.

Cuando el cumplimiento de las obligaciones previstas en una disposición legal corresponda a varias personas conjuntamente, responderán de forma solidaria de las infracciones que se cometan y de las sanciones que se impongan.

Artículo 80.- Las sanciones administrativas, sean o no de naturaleza pecuniaria, en ningún caso podrán implicar, ni directa ni subsidiariamente, privación de libertad. 
Artículo 9o.- Dentro de los límites establecidos en la ley, en la aplicación de sanciones pecuniarias se deberá precaver que la comisión de las infracciones tipificadas no resulte más beneficiosa para el infractor que el cumplimiento de las normas infringidas.

En la imposición de sanciones, la Administración deberá guardar la debida adecuación entre la gravedad del hecho constitutivo de la infracción y la sanción aplicada. Para tal efecto, a falta de norma legal especial que los establezcan, se considerarán los siguientes criterios para la graduación de la sanción a aplicar:

a) La existencia de intencionalidad o reiteración.

b) La naturaleza de los perjuicios causados.

c) La existencia de riesgos o peligro para terceros, derivados de la infracción cometida y su entidad.

d) La reincidencia, por comisión en el término de un año de más de una infracción de la misma naturaleza, cuando así haya sido declarado por resolución firme.

Artículo 10.- Las infracciones y sanciones prescribirán según lo dispuesto en las leyes que las establezcan.

Si las leyes respectivas no establecen plazos de prescripción, las infracciones prescribirán a los dos años de cometidas y las sanciones impuestas, a los tres años desde la notificación del acto sancionatorio firme.

La prescripción de la infracción se interrumpe con el inicio del procedimiento sancionatorio, desde que el presunto responsable sea notificado de dicha circunstancia conforme a la ley.

La prescripción de las sanciones aplicadas se interrumpe con el inicio del procedimiento de ejecución, desde que el sancionado sea notificado de dicha circunstancia conforme a la ley.

Artículo 12.- No podrá aplicarse sanción alguna por hechos que hayan sido previamente sancionados penal o administrativamente, cuando se acredite la identidad del sujeto, hecho y fundamento.

\section{TITULO III}

\section{Del procedimiento sancionatorio}

\section{Párrafo $1^{\circ}$}

Normas básicas

Artículo 13.- El procedimiento sancionatorio es una sucesión de actos trámites vinculados entre sí, emanados de la Administración y, en su caso, de los particulares interesados, que tiene por finalidad establecer la existencia de una infracción administrativa, determinar la o las personas responsables de la infracción y aplicar las sanciones administrativas que en derecho correspondan. 

instrucción y finalización.

El procedimiento sancionatorio consta de tres etapas: iniciación,

Artículo 14.- Los presuntos responsables de una infracción administrativa tendrán garantizados los siguientes derechos en los respectivos procedimientos sancionadores:

a) A ser notificado de los hechos que se le imputen, de las infracciones que tales hechos puedan constituir y de las sanciones que, en su caso, se le pudieran imponer, así como de la autoridad competente para imponer la sanción y de la norma que atribuya tal competencia.

b) A formular alegaciones y utilizar los medios de defensa y de prueba admitidos por el ordenamiento jurídico que resulten procedentes.

c) Los demás derechos reconocidos en la Ley No 19.880 .

Artículo 15.- En todo procedimiento sancionador se respetará la presunción de no existencia de responsabilidad mientras no se demuestre lo contrario.

\section{Párrafo $2^{\circ}$}

Iniciación del procedimiento

Artículo 16.- Los procedimientos sancionatorios podrán iniciarse de oficio o por denuncia.

Artículo 17.- Los procedimientos se iniciarán de oficio siempre que el órgano u organismo administrativo que tenga atribuida la potestad sancionatoria tome conocimiento, por cualquier medio, de hechos que pudieren ser constitutivos de alguna infracción administrativa de su competencia.

Sin perjuicio de lo anterior, siempre que la Administración tome conocimiento de hechos que puedan configurar una infracción administrativa cuya sanción compete a otro órgano u organismo, aquel que haya tomado conocimiento deberá comunicarlo circunstanciadamente al competente, para que éste inicie el respectivo procedimiento en caso de ser procedente.

Artículo 18.- Las denuncias de infracciones administrativas deberán ser formuladas por escrito al órgano u organismo competente, señalando lugar y fecha de presentación y la individualización completa del denunciante, quien deberá suscribirla personalmente o por su mandatario o representante habilitado.

Asimismo, deberán contener una descripción de los hechos concretos que se estiman constitutivos de infracción, precisando lugar y fecha de su comisión y, de ser posible, identificando al presunto infractor.

Artículo 19.- La denuncia formulada conforme al artículo anterior originará un procedimiento sancionatorio si a juicio del órgano u organismo competente, está revestida de seriedad y tiene mérito suficiente. En caso contrario, se podrá disponer la realización de acciones de fiscalización sobre el presunto infractor y si ni siquiera existiere mérito para ello, se dispondrá el archivo de la misma por resolución someramente fundada, 
notificando de ello al interesado.

\section{Párrafo $3^{\circ}$ \\ Instrucción del procedimiento}

Artículo 20.- La instrucción del procedimiento sancionatorio se iniciará con una formulación precisa de los cargos, que se notificará al presunto infractor por carta certificada en el domicilio que tenga registrado ante el respectivo organismo de la Administración o en el que se señale en la denuncia, según el caso, confiriéndole un plazo de 15 días para formular los descargos.

La formulación de cargos deberá señalar la forma en que se ha iniciado el procedimiento, una descripción de los hechos que se estiman constitutivos de infracción y de la fecha de su verificación, la norma eventualmente infringida y la disposición que establece la infracción, la sanción asignada por la ley a esa infracción, el plazo para formular descargos y la individualización del organismo que instruye el procedimiento, su dirección y horarios de atención.

Artículo 21.- Recibidos los descargos o transcurrido el plazo otorgado para ello, el organismo instructor examinará el mérito de los antecedentes y, en caso que los hechos investigados no le consten fehacientemente, ordenará la realización de las pericias e inspecciones que sean pertinentes y la recepción de los demás medios probatorios que procedan.

En todo caso, el organismo instructor dará lugar a las medidas o diligencias probatorias que solicite el presunto infractor en sus descargos, que resulten pertinentes y conducentes. En caso contrario, las rechazará mediante resolución motivada.

Artículo 22.- Los hechos constatados por funcionarios a los que se reconoce la condición de autoridad o la calidad de ministro de fe, y que se formalicen en el expediente respectivo, tendrán valor probatorio, sin perjuicio de los demás medios de prueba que se aporten o generen en el procedimiento.

Artículo 23.- Los hechos investigados y las responsabilidades de los infractores podrán acreditarse mediante cualquier medio de prueba admisible en derecho, los que se apreciarán en conciencia.

De las medidas o diligencias probatorias que disponga el organismo instructor, sea de oficio o a petición del presunto infractor, se dará noticia a éste con la antelación suficiente, mediante carta certificada en que se indicará el lugar, fecha y hora en que se practicará la prueba.

Artículo 24.- Realizadas las diligencias probatorias o una vez presentados los descargos o vencido el plazo para ello, según el caso, se recabarán los informes que correspondan conforme a las disposiciones legales, y los que se juzguen necesarios para resolver, citándose el precepto que lo exija o fundamentando la conveniencia de requerirlos, según corresponda.

Salvo disposición legal expresa en contrario, los informes que se recaben serán facultativos y no vinculantes. 


\section{Párrafo $4^{\circ}$ \\ Finalización del procedimiento}

Artículo 25.- La resolución que ponga fin al procedimiento sancionatorio será fundada y resolverá todas las cuestiones planteadas en el expediente, pronunciándose sobre cada una de las alegaciones y defensas del imputado, y contendrá la declaración de la sanción que se imponga al infractor o su absolución.

La resolución final deberá dictarse dentro de los treinta días siguientes a aquel en que se haya evacuado la última diligencia ordenada en el expediente.

Artículo 26.- La resolución que aplique sanciones deberá indicar los recursos administrativos y judiciales que procedan contra ella, los órganos judiciales y administrativos ante el que deban presentarse y el plazo para interponerlos, sin perjuicio que los afectados puedan ejercitar cualquier otro que estimen oportuno.

Artículo 27.- Transcurrido el plazo de seis meses contado desde la formulación de cargos, sin que se haya dictado resolución final en el respectivo procedimiento sancionatorio, el imputado o presunto infractor podrá denunciar el incumplimiento de dicho plazo ante el organismo instructor, requiriéndole decisión sobre el particular. Dicho organismo deberá otorgar recibo de la denuncia, con expresión de su fecha y hora de recepción.

Si el organismo requerido no dicta la resolución que pone término al procedimiento sancionatorio en el plazo de diez días contados desde la recepción de la denuncia, se entenderá que el presunto infractor ha sido absuelto de los cargos que se le hubieren formulado.

En el caso del inciso precedente, el afectado tendrá derecho a que se certifique el término del procedimiento sancionatorio en virtud del vencimiento del plazo y el efecto que a dicha circunstancia atribuye la ley.

\section{TITULO IV}

De los recursos

Artículo 28.- Los actos administrativos que se originen en los procedimientos sancionatorios regidos por esta ley, serán susceptibles de revisión a través de los mecanismos y recursos previstos en el Capítulo IV de la Ley No 19.880 y a través del reclamo de ilegalidad que se establece en el artículo siguiente.

La interposición de los recursos de reposición y jerárquico, en su caso, suspenderán el plazo para deducir reclamo de ilegalidad.

Artículo 29.- Podrá deducirse reclamo de ilegalidad en contra de los actos administrativos que se originen en procedimientos sancionatorios regidos por esta ley, cuando no se ajusten a la ley, a los reglamentos o a las demás disposiciones aplicables.

El reclamo deberá deducirse por el afectado dentro del plazo de diez días hábiles, contado desde la notificación del acto, ante la Corte de Apelaciones correspondiente a su domicilio. Si el acto afectare a más de una persona o entidad, cuyos domicilios correspondieren a territorios jurisdiccionales de diferentes Cortes, será competente para conocer de todas las reclamaciones a que haya lugar, aquella que corresponda al domicilio 
de la autoridad que haya expedido el acto administrativo reclamado.

Artículo 30.- Las sanciones que impongan multa serán siempre reclamables y no serán exigibles mientras no esté vencido el plazo para interponer la reclamación, o ésta no haya sido resuelta.

Para interponer la reclamación contra una multa deberá acompañarse boleta de consignación a la orden de la Corte, por el 25\% del monto de la misma.

Artículo 31.- Una vez acogida a tramitación, la Corte de Apelaciones dará traslado de la reclamación al organismo de la Administración que hubiere dictado el acto impugnado, notificándole por oficio y otorgándole un plazo de diez días hábiles para formular sus observaciones, contado desde que se notifique la reclamación interpuesta.

La Corte no podrá decretar medida alguna que suspenda los efectos del acto reclamado, cuando la suspensión de los efectos de la resolución pueda afectar la seguridad o salubridad de las personas y, en general, cuando concurran circunstancias de daño o peligro inminente que exijan su inmediata corrección.

Artículo 32.- Evacuado el traslado por la Administración, o vencido el plazo de que dispone para formular observaciones, el tribunal ordenará traer los autos en relación y la causa se agregará extraordinariamente a la tabla de la audiencia más próxima, previo sorteo de la Sala.

La Corte podrá, si lo estima pertinente, abrir un término probatorio que no podrá exceder de siete días, y escuchar los alegatos de las partes.

La Corte dictará sentencia dentro del término de quince días. Contra la resolución de la Corte de Apelaciones se podrá apelar ante la Corte Suprema, dentro del plazo de diez días hábiles, la que conocerá en la forma prevista en los incisos anteriores.

Artículo 33.- En caso de no acogerse el reclamo, el monto de la consignación se entenderá abonado al pago de la multa y, en caso de acogerse, se ordenará su devolución por la Tesorería General de la República, debidamente reajustada en la forma que señalan los artículos 57 y 58 del Código Tributario.”. 